\title{
A conformação dos ecomuseus: elementos para compreensão e análise *
}

Heloisa Barbuy

Museu Paulista/Universidade de São Paulo

Introdução

Ecomuseu: um museu voltado para o ambiente no qual está inserido. Mas com que sentido e de que modo? A simples menção do termo ecomuseu, uma infinidade de idéias, noções, imagens podem vir à mente do museólogo, do historiador, do antropólogo, de qualquer profissional, enfim, que atue na área dos museus. $O$ tema, de tão difundido, traz em seu bojo o desafio de lidar com as noções pré-estabelecidas - e as paixões - do leitor ou do interlocutor. Mas entre nós estas noções parecem ainda muito confusas e carecem de maior embasamento. Embora chegue a ser desgastado, o assunto foi, aqui, pouco debatido realmente. Há, freqüentemente, uma interpretação distorcida do que sejam os ecomuseus, fruto da pouca informação que se tem, finalmente, sobre este tipo de instituição e de política cultural, ou - como definiu François Hubert (1985: 186)-de ferramenta patrimonial ("outil patrimonial"). Houve uma grande difusão do que seja a filosofia de base dos ecomuseus, assim como, de um modo geral, do movimento que se denomina "nova museologia". Uma filosofia guiada pelo sentido de dessacralização dos museus e, sobretudo, de socialização, de envolvimento das populações ou comunidades implicadas em seu raio de ação. Entretanto, raramente essa difusão nos chegou acompanhada de elementos que permitissem compreender como se dão, mais concretamente, as experiências dos ecomuseus e quais as suas linhas de filiação. Por isto não poderemos escapar, desta vez, de um trabalho em boa parte retrospectivo e descritivo. Por inspiração em seu próprio "dístico", queremos
*Parte das afirmações contidas neste texto foi elaborada com base em anotações feitas durante duas viagens de estudos à França, a partir da observação direta ou das explicações dadas por meus interlocutores: a primeira delas foi em 1988, quando fiz estágios no Museu de Artes e Tradições Populares (Paris) e no Ecomuseu de Saint-Nazaire, assim como no Museu da lle-de-France (Sceaux); a segunda foi em 1995 . quando pude participar de um programa para profissionais de Cultura da América Latina, oferecido pelo Ministério da Cultura da França, em parte realizado no $\mathrm{Mu}$ seu da Bretanha (Rennes), que tem, como anexo, o Ecomuseu do Pays de Rennes-La Bintinais. 
ver os ecomuseus "no tempo e no espaço", deixando brotar as questões ao longo de nosso percurso. E para tanto, vamos examinar o caso francês, que se tornou, internacionalmente, a grande referência deste tipo de formação museológica.

Um novo sentido para o patrimônio

A França, quando começou a criar aqueles que viriam a ser chamados de ecomuseus, tinha já uma longa tradição museológica, com exaustivos trabalhos de tombamentos, coletas e documentação de patrimônio cultural (móvel ou imóvell, organização, enfim, de acervos. Tinha mesmo, como era também o caso da Itália, Inglaterra, Alemanha, Áustria e outros países, um excesso de espírito classificatório, herdado dos naturalistas. As novas experiências de museus mais preocupados com seu papel social representaram - e representam - uma corrente de ar fresco dentro de um ambiente cujo ar chegava a ser viciado pelas antigas práticas, guiadas por um "patrimonialismo" como fim em si. Mas mesmo assim, ou justamente por contarem com um passado de tradição patrimonialista, os ecomuseus não abandonaram simpleșmente as idéias de acervo e de patrimônio, como crêem alguns. É verdade que, em sua origem, contrapunham-se às tendências patrimonialistas, no sentido de querer afirmar "o museu para o homem" e não "o homem para o museu". Tinham uma ânsia anti-patrimonialista mas relativamente ao sentido que se conferia ao patrimônio e não querendo realmente abolir as noções de patrimônio e de acervo e sim transformálas e ampliá-las, como de fato ocorreu.

O acervo não é indesejado ou banido; ao contrário, é ampliado, tanto no sentido de sua natureza como no de seu significado, abrangendo bens imóveis e territórios inteiros, além de espécimes vivos e de bens imateriais. É verdade que a postura dos empreendedores dos ecomuseus causou certas interpretações indevidas, talvez por chocar os partidários dos acervos-fetiche. Neste sentido, os ecomuseus criaram um paradoxo em relação aos acervos, negando, de início, a irrefutabilidade de um certo valor do objeto pelo objeto querendo, de certo modo, "épater le bourgeois" - para só depois atribuir-the valor muito mais amplo:

"A crítica radical à instituição museal - o deus objeto - valor "adorado" em seus templos
- decorre da preocupação de "mudar o sentido do trem": a ligação existente com a
comunidade humana que produz o objeto, que o utiliza, a significação concreta ou
simbólica desta ligação, torna-se o essencial, tendo como consequêencia uma nova
abordagem do patrimônio..."
(Hubert, Joubeaux \& Veillard, orgs. $1983: 6)$

É preciso compreender todo este processo, que se deu num contexto em que os chamados museus tradicionais tinham já - na França e em outros países europeus - uma solidez e um alcance extraordinários, e no contexto, aliás, dos movimentos de contracultura dos anos 70. Naquele momento a negação chocante era uma estratégia para processar um movimento em novo sentido. Mas já lá se vão mais de vinte anos...

Os ecomuseus deram uma grande ênfase a seu papel social e propuseram formas - por vezes românticas - de interação social de comunidades e 
por esta marca ficaram conhecidos. Entretanto, todo o processo social lou socializantel desencadeado ou desejado pelos conceptores dos ecomuseus foi proposto, exatamente, em torno do patrimônio, este representado, em grande medida, por acervos. Mathilde Bellaigue define quatro elementos como constitutivos dos ecomuseus: o território, a população (como agentel, o tempo e - o patrimônio. E acrescenta: "quando falamos de patrimônio, falamos de patrimônio total: tanto as paisagens, sítios, edificações, como os objetos que são portadores de história ou de memória" (Bellaigue 1993: 75). Que esses objetos sejam recolhidos ou não para dentro de um museu, isto depende de cada contexto cultural e de cada projeto museológico mas em nenhum momento propôs-se que os objetos deixassem de ser inventariados. Em nenhum momento os criadores dos ecomuseus negaram a importância do objeto como documento histórico ou documento de memória. Isto já se tornou um equívoco histórico. Em 1974, discorrendo sobre o conceito de patrimônio, num curso promovido pela FAU/USP, Hugues de Varine, uma das pessoas mais envolvidas com o movimento dos ecomuseus, abordou várias questões relativas aos inventários e aos bens culturais.

Georges Henri Rivière, provavelmente a mais importante figura do movimento francês de renovação museológica do pós-guerra, foi o responsável pela criação de muitos museus e ecomuseus na França e em outros países e deu importância absoluta aos acervos como portadores de informação, assim como de carga simbólica e afetiva. Basta percorrer alguns dos museus por ele projetados ou com os quais colaborou para ter a certeza da importância conferida aos bens culturais - e à pesquisa em torno do patrimônio, geradora inclusive de acervos. $\mathrm{O}$ Museu Nacional de Artes e Tradiçōes Populares, de Paris, por ele criado, é considerado, na França, um dos poucos museus de linha universitária pois congrega vários pesquisadores do CNRS (Conselho Nacional de Pesquisas Científicas), contratados para ali desenvolver pesquisas em torno da etnografia francesa (redundante dizer, em torno da cultura material)!

\section{Quadro geral de bibliografia}

Quanto à bibliografia, é bastante dispersa em artigos publicados em revistas acadêmicas ou não, em catálogos e guias de museus e ecomuseus e algumas análises em livros, como as de Dagognet (1984), Davallon (1986) e Poulot (1994). No início dos anos 70 , quando eclodia o movimento dos ecomuseus, vários artigos foram publicados na revista de divulgação Museum, da Unesco, organização em cujo seio havia sido fundado o Conselho Internacional de Museus - ICOM, por Rivière e seu grupo, logo após a II Guerra Mundial. Em 1985, quando faleceu Rivière, foi publicado um número desta revista especialmente dedicado ao tema, sob o título "Images de l'écomusée". Antes disso, em 1983, preocupado com a falta de critérios com que se vinha tratando o assunto, os desvios sofridos e a forma indiscriminada com que se vinha denominando de "ecomuseu" as mais diferentes iniciativas, um grupo representativo de profissionais reuniu-se no Museu da Bretanha para debater a questão. Do encontro resultou a publicação Découvrir les écomusées (Hubert, Joubeaux \& Veillard, orgs. 19831, que se tornou uma das fontes mais importantes para quem queira compreender 0 fenômeno. Há, ainda, vários anais de outros encontros voltados para o tema,
1. As indicações das influências teóricas ligadas às origens do Museu Nacional de Artes e Tradições Populares são dadas por Cuisenier \& Tricornot (1987: 15): "a dos folcloristas, é claro, na primeira linha, entre os quais é preciso citar Arnold Van Gennep, cujo monumental Manual foi publicado de 1937 a 1958; a dos sociólogos e da Escola francesa de Sociologia também, conduzidos por Marcel Mauss; a dos historiadores e da Escola dos Annales, conduzidos por Lucien Febvre; e a dos geógrafos e dos lingüistas, trazida porAlbert Demangeon e Albert Dauzat". Tudo leva, pelo que se pode ver, ao que poderiamos hoje chamar de antropologia histórica do quotidiano. 
2. Isabelle Collet (1987a) utiliza-se dos seguintes documentos: "L'Ethnographie traditionnelle et les musées cantonaux" (Sébillot 1886-1887: .920) e "Instructions sommaires relatives aux collections provinciales d'objets ethnographiques" (Sébillot \& Landrin 1897: 465-475) Sébillot era secretário geral da Sociedade de Tradições Populares e Landrin, conservador (curador) do Museu de Etnografia doTrocadero, atual Museu do Homem.

3. Lista de campos proposta por Sébillot \& Landrin, em 1896/97. entre eles um organizado pela Secretaria Municipal de Cultura do Rio de Janeiro, em 1992.

Especialmente sobre Rivière, La Muséologie selon Georges Henri Rivière (1989) é obra de referência, organizada por seus alunos e seguidores, a partir de anotações de aulas e de várias experiências profissionais. Um "Dossier écomusée" consta também deste livro (p. 146-165).

De todo modo, no caso dos ecomuseus, a bibliografia não basta: as "obra completas" incluem, por certo, os próprios ecomuseus e, como veremos, algumas outras formações museológicas.

Genealogia: da etnografia regional aos ecomuseus

Vejamos, antes de mais nada, como e por que surgiram os ecomuseus. A História, recentemente, tem privilegiado a análise dos processos de ruptura e não a busca de raízes. No caso dos ecomuseus, as raízes representam, justamente, a ruptura com certos padrões de museus e de Museologia. $O$ desenvolvimento e a maturação de movimentos voltados para uma chamada cultura popular, engendrados desde o final do século XIX, ganharam vulto e espaço na área dos museus no século XX e, em termos de Museologia, no início dos anos 1970, romperam (ou apresentaram-se como alternativa) com as tradições vindas do século XIX, dos museus de belas artes fixados nas obras primas e únicas, dos museus enciclopédicos de história natural e dos museus de história, calcados na história factual e oficial. Por isto mesmo vale a pena nos remetermos aos seus primeiros tempos e aos movimentos que os antecederam.

Para isto podemos deter nossas lentes, ainda que rapidamente, sobre as próprias origens dos museus de antropologia histórica lé disto que se trata, afinal), na França do século XIX, em duas de suas vertentes: a primeira, os museus regionais de folclore ou tradições populares (etnografia regional); a segunda, interligada à primeira, as representações do mundo rural nas exposições universais.

No século XIX, enquanto os modelos mais prestigiosos de museus eram os de belas artes e os de história natural, outros movimentos se fortaleciam, germinando os museus de culturas locais, os museus de folclore. E enquanto no decorrer do século XIX, dentro dos interesses imperialistas, os museus de antropologia ganhavam também destaque como centros de estudo de culturas exóticas, na virada para o século XX iniciam-se as correntes regionais, que, nos museus europeus, tendem mais à auto-representação cultural do que à representação do outro.

Para traçar as origens dos museus franceses de etnografia regional, Isabelle Collet analisa dois textos de Paul Sébillot lo segundo em co-autoria com Armand Landrin) que, produzidos no final do século XIX, tinham "o objetivo de dar indicações teóricas e práticas aos coletores de objetos etnográficos destinados a serem conservados no museu" (Collet 1987a) ${ }^{2}$. A partir desses dois documentos ela nos mostra uma etnografia regional nascente e uma correspondente museologia etnográfica, dando também - e conjuntamente - seus primeiros passos: a busca dos grandes campos de análise e coleta de testemunhos materiais ("habitação, mobiliário e interiores, dependências da casa, agricultura, alimentação, ofícios não agrícolas, indumentária, vida humana, jogos, artes populares, cultos, superstições" $\left.\right|^{3}$; as tentativas de circunscrição das tipologias de interesse (objetos 
"rústicos", "habituais", "de uso corrente"); os cortes temporais /o período de longa duração anterior ao desenvolvimento dos meios de transporte e comunicação que romperam o isolamento do campo); a identificação do indivíduo pelo seu ofício e das populações pelo modo de vida que se associa ao trabalho que marca suas respectivas regiões, tal como o plantio da uva e a produção de vinho ou outros.

Para os que conhecem, hoje, os museus de etnografia regional e os ecomuseus voltados para culturas rurais, nada disso soa estranho. Ao contrário, é fácil reconhecer certas permanências, ao menos quanto a aspectos formais. Ao longo de sua história, os museus de etnografia regional receberam diferentes orientações e sentidos. Na França, inicialmente tenderam a um sentido de registro científico de culturas rurais em desaparecimento, em face da aceleração dos processos de industrialização ${ }^{4}$. A estrutura agrária francesa havia sofrido poucas transformações durante os séculos XVIII e primeira metade do XIX mas de todo modo, a industrialização e todas as mudanças sociais a ela correlatas avançavam. A desestabilização das antigas estruturas coincide - e não por acaso - com a criação das primeiras sociedades científicas para estudo das tradições populares regionais (floclore) e dos primeiros museus de etnografia regional. Ao lado do caráter científico, revestiram-se, também, de tendências nostálgicas românticas, seja como trincheiras de resistência contra o capitalismo, seja como pontos de convergência de afirmações regionalistas. Mas a emergência das coletas e formação de coleções que testemunham aspectos escothidos de determinadas culturas populares são também, como afirma Collet, sinal de "uma tomada de consciência, por certos eruditos, do interesse e da fecundidade de uma sabedoria popular que é o caso de interrogar e mesmo de reutilizar" (Collet 1987a: 88) ${ }^{5}$.

As exposições universais da segunda metade do século XIX e primeiras décadas do século XX são outra matriz de representações do mundo rural $e_{\text {, }}$ freqüentemente, eram os cientistas-curadores de museus que organizavam, nestas ocasiões, as partes consideradas de cunho científico, como era o caso das

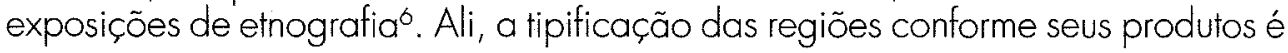
uma constante:

\footnotetext{
"Cada região da França está ali representada pelo conjunto de seus produtos; uma região produz os têxteis, outra os óleos; esta os vinhos, aquela o trigo. E uma espécie de geografia agrícola etiquetada e catalogada com segurança e comprovação. Em cinqüenta minutos pode-se aprender a estatística completa da produção vegetal.

Com exceção dos rebanhos e dos animais domésticos, que terão uma exposição à parte, tudo o que constitui a vida rural está representado no Quai d'Orsay".

(Jules Richard (1889: 143), sobre a parte dedicada à agricultura na Exposição Universal de 1889, Paris).
}

Seja nas partes relativas à agricultura, seja em outras seções, as exposições universais são ocasiões em que se estabelecem padrões expositivos (ou, pode-se dizer, museográficos). Ainda na de 1889, a Exposição Retrospectiva do Trabalho mostra, por exemplo, a reconstituição do interior de uma casa camponesa (Fig. 1) ou a oficina de um fabricante de alaúdes (Fig. 5), ambas do século XVHII, temáticas e práticas expositivas que veremos repetida até os dias de hoje (cf. Figs. 3 e 6). Vemos configurar-se, nas exposições universais, uma tipificação de culturas e de tipos regionais, através das atividades de produção e dos produtos, o indivíduo sendo identificado por seu ofício, assim como por seu modo de vestir,
4. Assim também no Brasil, a Etnografia ganhou identificação com os estudos sobre culturas indígenas em vias de desaparecimento.

5. Um caso significativo de museu originado no final do século XIX, a partir de coleções de cuItura regional é o do Museu da Bretanha (cf. Veillard 1987).

6. Em um número da revista Museum de dicado ao tema "museu e agricultura", Iván Balassa (1972) afirma que os museus de agri cultura têm sua origem nas exposições nacionais e universais da segunda metade do século XIX e faz um breve a panhado da história e diferentes características desse tipo de museu. 
estes elementos caracterizando uma dada cultura. Por exemplo, em 1889, "na exposição de agricultura e alimentação, ocorre a tipificação de culturas através dos produtos e das atividades de produção mas também da indumentária e de outros objetos, como no caso da exposição das vacas bretãs, em que, lao lado dos animais), uma mulher com trajes típicos de sua região, inclina um galão de leite, tendo à sua frente uma mesinha com leiteira e xícaras, onde terá servido o produto ordenhado (Fig. 7). Enfim, cultura e atividade econômica, ligadas por certo, sofrem, na Exposição Universal, um processo de síntese, cujo resultado são imagens-signos, que ensinam conceitos ou definições de culturas 'pelo aspecto' ", e isto por meio de configurações visualmente apreensiveis (Barbuy 1995: 56). As formas de apresentação são extremamente próximas das atuais mas a diferença está no sentido que se dá a essas configurações: nas exposições universais do final do século XIX este tipo de reconstituição visava produzir efeitos comparativos para valorizar o progresso e o tempo presente; nos ecomuseus do final do século XX pretendem representar identidades culturais.

Alguns princípios estão na origem dessas exposições de caráter didático: o ensino pelo aspecto, a lição de coisas são noções que se imprimem ao ensino francês no final do século XIX (cf. Gaulupeau 1988: 35), assim como os modelos didáticos em cera e montagens de cenas e cenários. É todo um didatismo que se desenvolve, nos mais diferentes campos, através da visualidade: as "reconstituições" de ambientes, os dioramas, os manequins realísticos, tudo organizado para a compreensão pela visão (cf. Barbuy 1995: 36-47). Tais práticas estavam presentes nos museus de etnografia (exótica e regional) e nas apresentações etnográficas das exposições universais. O próprio termo museu, naquele momento, significa "a exposição organizada de imagens ou objetos que possam, por seu 'aspecto', ensinar, instruir. Assim, é prioritariamente através de suas exposições e da experiência sensível que elas permitem, que os museus disseminam a instrução" (Barbuy 1995 : $46)$.

Foi também no âmbito da Exposição Universal de 1889 que se realizou - 1 Congresso Internacional de Tradições Populares e foi nesta ocasião que Armand Landrin, do Museu de Etnografia do Trocadero, apresentou o projeto de um museu das províncias da França - um museu de artes e tradiçōes populares -, que se propunha como um centro de estudos, um museu científico (ct. Dias 198'7: 191194).

Na Exposição Universal de 1900, assim como nas anteriores - e ainda com mais ênfase pela passagem do século -, organizam-se várias exposiçōes retrospectivas. Há também uma para a seção agrícola: o sentido geral da seção era de fomentar, junto aos agricultores, o uso de equipamentos modernos; a exposição retrospectiva, anexa, surtiria efeito de comparação, apresentando cerca de 3.000 utensílios da antiga agricultura (cf. Collet 1987b: 1011). E, se na de 89, a agricultura ocupava uma área em separado, no Quai d'Orsay, na de 1900 estava dentro do Palácio das Máquinas, juntamente com outros equipamentos industriais, o que se deve a seu próprio processo de mecanização e conseqüente distanciamento das antigas práticas agrícolas. Era exatamente para valorizar os novos métodos que se organizavam as exposições retrospectivas.

Entretanto, muito embora variando de "a a $z$ " quanto a seus propósitos, tendências, orientações intelectuais e receptividade popular, os museus de etnografia 
regional - ou de antropologia histórica, em muitos casos - (e as exposições universais, em seus aspectos etnográficos), guardam desde os primeiros tempos, na tipologia de seus acervos e em vários aspectos de suas exposições certas características comuns, que alcançaram o tempo de Georges Henri Rivière e foram por ele ricamente exploradas la presença marcada, nos acervos, de instrumentos de trabalho, as indumentárias regionais com o uso de manequins, as técnicas regionais de construção, etc.). Ele foi, aliás, não apenas um herdeiro dessas primeiras iniciativas mas quase um seu contemporâneo.

Na verdade, o final do século XIX está bem ligado aos anos 1930, quando Georges Henri Rivière daria os primeiros passos em direção aos ecomuseus, assumidamente inspirado na fórmula dos museus ao ar livre lou museus a céu aberto, como se tem, também, traduzidol, criada na Suécia em 18917. Inicialmente visava a valorização da arquitetura rural francesa, o que continuou sendo um aspecto particularmente explorado em suas obras subseguintes e na de seus colegas e seguidores.

O primeiro projeto neste sentido data de 1936 e foi seguido de outros que, como este, não puderam se realizar na forma desejada, o que só aconteceria bem mais tarde. Em 1937 - no entre-guerras e ainda no fluxo das exposições universais - na "Exposição Internacional das Artes e Técnicas da Vida Moderna", a parte relativa à agricultura fica sob responsabilidade do Front Popular (partido socialistal, ao qual Georges Henri Rivière era ligado ${ }^{8}$. Rivière torna-se, assim, responsável pela exposição retrospectiva sobre a vida rural, a que dá o nome de "museu da terra" (musée du terroir). O conjunto correspondia às posições do Front Popular, que era favorável à modernização dos equipamentos, desde que houvesse um "equilíbrio entre as organizações coletivas e a unidade familiar de produção" lcf. Collet 1987b: 107-110).

Ecomuseus de parques regionais

Somente em 1969 Rivière conseguiria, finalmente, inaugurar seu museu ao ar livre, trabalhando patrimônio natural e cultural dentro de um programa antropológico, em torno da cultura regional das Landes de Gascogne (cf. Rivière 19871.

Rivière desenvolveu extensos trabalhos em torno de parques regionais franceses 9 , a cujos resultados se deu mais tarde o nome de ecomuseus. Esta corresponde, conforme a análise de Hubert (1985) à primeira geração de ecomuseus ${ }^{10}$.

A constatação do empobrecimento e êxodo de certas regiões francesas, nos anos 60, dá ensejo a uma política de reaproveitamento, para o turismo, de algumas zonas consideradas em degradação. Com isto criam-se vários parques regionais, cercados por uma infra-estrutura de hotéis e outros equipamentos.

Convocado a colaborar, relativamente a questões de patrimônio cultural, Georges Henri Rivière passa a trabalhar pela idéia de preservação de exemplares de arquitetura rural tradicional francesa dentro dos parques. Transportar ou não transportar construções de outros lugares para dentro dos parques; reunir, num mesmo local, uma série formada por exemplares de diferentes regiões ou manter apenas construções características da região a que pertence cada parque: estas
7. Sobre o museu sueco de Skansen/Nordiska Museet, ver Baehrendtz, Biörnstad \& Palma (1982) e também, Alexander (1978:84-86).

8. Sobre as relações de Rivière com o Front Popular e sua importância na criação de centros e movimentos de folclore e artes populares ver Ory (1989: 59-60).

9. Para uma visão geral sobre os parques regionais franceses, ver Morineaux (1977).

10. François Hubert (1985) identifica três gerações de ecomuseus: a primeira, dos de parques regionais; a segunda, marcada pelo Ecomuseu do Creusot; a terceira geração, a dos ecomuseus pouco criteriosos, considerados por Hubert como "desvios". "A quarta geração escrevia ele em 1985 está por ser inventada". 
11. Sobre o nascimento do Museu de Etnografia de Paris, hoje Museu do Homem, ver Nélia Dias (1991). Nesta mesma obra, um ítem sobre "Armand Landrin e o projeto de um museu" (Ib.: 191-194) permite ver a presença, já no final do século XIX, da idéia do museu-síntese $\mathrm{e}$ da rede de museus de provincia, que seria alimentada e desenvolvida, mais tarde, por Georges Henri Rivière. são algumas das questões que foram debatidas na ocasião (cf. Gestin 1989: 155). De qualquer forma, porém, vingou a causa da preservação da arquitetura rural tradicional, que se tornou, inclusive, temática recorrente nos museus de "linha Rivière", tanto no âmbito da pesquisa como das exposições (ver Figs. 8 e 9).

A arquitetura rural acabou por ser, na verdade, um módulo inicial que, desenvolvendo-se, ampliou-se para a idéia de um trabalho museológico em torno de todo um modo de vida: chegava-se, assim, ao casamento entre as tradições dos museus de etnografia regional e as idéias de libertação do museu relativamente a seus muros e seu elitismo, para criarem-se os museus de território, de patrimônio lato sensu e que envolvessem as populações locais, num processo de revitalização.

O Museu Nacional de Artes e Tradições Populares, Paris: padrões museológicos de referência

Naquele mesmo ano de 1969, a seção francesa do Museu do Homem de Paris, sustentada por Rivière desde os anos 1930, ganharia finalmente sede própria, como Museu Nacional de Artes e Tradições Populares, conhecido na França simplesmente como ATP. A compreensão do ATP permite o acesso às linhas mestras de todo o pensamento e do método de Rivière, da Museologia que ele implantou em diversos museus e ecomuseus franceses e estrangeiros.

Desde sua criação, em 1898, o Museu de Etnografia do Trocadero, em Paris (hoje Museu do Homem), contava com acervos relativos a culturas tradicionais francesas. Em 1937 seria criado um museu para este núcleo francês (quase autônomo, mas ainda dentro do mesmo prédio), sob a direção de Georges Henri-Rivière, que fez dele uma espécie de "central" de sua obra, por mais de trinta anos. Esta central não o era apenas no sentido de sede operacional mas também - e principalmente - no sentido conceitual: Rivière o concebeu como um "museu-síntese" das culturas tradicionais francesas, que se interligaria com museus mais pontuais, no projeto de uma rede de museus de etnografia regional ${ }^{1}{ }^{1}$. Alguns desses museus chegaram a ser implantados mas a idéia da rede não se completou. Entretanto, até hoje não é difícil identificar a marca de Rivière em vários museus no interior da França, sejam organizados por ele próprio, sejam por sua influência.

Podemos apontar alguns desses elementos a partir do próprio ATP de Paris, que, como dissemos, pode ser entendido como uma espécie de central. Dizem respeito à natureza dos acervos coletados em função de linhas de pesquisa pré definidas e às formas de explorá-los museologicamente.

Observe-se que Rivière insistiu constantemente na formação sistemática de acervos como resultado consistente de pesquisas, sobretudo pesquisas de campo. Propunha que para o estudo das culturas francesas fossem aplicados os métodos de pesquisa e coleta já utilizados nos estudos relativos à etnografia do exótico (culturas das colônias francesas). No sentido de não provocar perda de informações sobre a correlação existente entre diferentes objetos, Rivière defendia, entre outros meios, a coleta e a exibição de ambientes inteiros:

"as coisas reais integradas são os objetos que participaram de um mesmo meio, adquiridas em sua integridade ou reagrupadas pelo museu, as quais podemos chamar de 'unidades ecológicas". Interpretadas desse modo, decodificadas pelo visitante, testemunham o contexto humano, com mais intensidade do que o fazem as coisas isoladas. Assim é o 
conteúdo completo de um interior doméstico (period room), de um navio, de um túmulo, transferido para o museu, com ou sem seu subcontexto de arquitetura doméstica, naval ou funerária" (Rivière 1973: 28).

Um dentre os exemplos que poderíamos dar neste sentido é o da Sala de Guillaume e Catherine Deuffic (Fig. 3) (cf. Cuisenier \& Tricornot 1987: 79-81) ou o da Queijaria, na região do Cantal (Fig. 4) (cf. Cuisenier \& Tricornot 1987: 106-107). Trata-se de ambientes inteiros que se mantiveram em meios não alcançados pelo processo de industrialização. Estavam prestes a serem desmontados e demolidos, quanido foram localizados por equipes de pesquisa do ATP e adquiridos como acervo. Remontados dentro do Museu, são cercados por certos dispositivos museográficos como iluminação variável e narrativas gravadas, à disposição do visitante, que explicam as atividades desenvolvidas em cada um dos ambientes, envolvendo os diversos objetos que os compõem. São, assim, ambientes que podem ser inseridos no quadro das chamadas "reconstituições museológicas".

Duas são as principais discussões que se abrem em relação às reconstituições. A primeira, que pode ser encontrada, entre nós em Myriam Sepúlveda dos Santos (apud Abreu 1994) diz respeito à artificialidade dos ambientes construídos em museus. Em relação a isto, os interiores que se exibem no ATP, embora tornando-se inevitavelmente artificializados pelo simples fato de serem apresentados em um museu, são casos diferentes das chamadas "reconstituições de ambiente", nas quais falta a confiança em que todos os objetos reunidos, cada qual de uma procedência diferente (ainda que próxima), pudessem ter formado, de fato, um ambiente em seu contexto de origem.

A segunda é formulada pelo italiano Alberto Cirese, que, também voltado para museus de folclore de culturas rurais e buscando, ele também, uma solução científica para exposições de objetos etnográficos, privilegia as relações existentes entre os objetos, apreensiveis apenas se levarmos em consideração outros tantos elementos - concretos e abstratos - relativos a seus respectivos contextos. Poderíamos presumir que Cirese estivesse de acordo com o que se fez na Galeria de estudos do ATP, mas nem sempre com o que se fez na Galeria Cultural daquele museu ou em vários ecomuseus e museus de etnografia regional: as reconstituições de quadros de vida. "A vida de um museu - diz Cirese - está em reconstruíta em seu próprio nivel, dispondo o real segundo linhas de inteligibilidade que o real não apresenta imediatamente" (Cirese 1967: 49). Esclarecendo este ponto, vejamos, no ATP, duas abordagens museográficas diferentes, relativas ao espaço doméstico, cada qual com seu valor: a primeira, a sala da família Deuffic, que já mencionamos acima (Fig. 3), que reconstitui um ambiente tal como ele foi vivido, possibilitando estabelecer quase qualquer relação entre os objetos, conforme os referenciais do próprio observador e exercendo, talvez mais que tudo, uma função evocativa, transportando o visitante para uma espécie de "história vivida"; a segunda abordagem (Fig. 2) cria um sistema articulado de objetos relacionados com a preparação e o consumo domésticos de alimentos, justamente retirando-os de seu espaço habitual (a casa) e permitindo uma leitura mais direta da relação existente entre eles. Esta leitura, então, seria mais evidente na exposição assim concebida do que no próprio espaço doméstico de origem. 10 mesmo raciocínio 
12. Atualmente, nesta década de 1990, o ATP vem passando por várias revisões e já não se restringe, em suas linhas de pesquisa e em suas exposições temporárias, à França pré-industrial. Várias discussões a respeito de seus objetivos vêm se desenrolando, tendo-se aventado, re centemente, até mesmo a absurda hipótese de seu retorno ao Museu do Homem, o que foi objeto de reações imediatas por parte de intelectuais franceses, entre eles Claude Lévi-Strauss.

13. OATP foi pioneiro na criação de duas áreas diferenciadas de exposições: a primeira, para o grande público, chamase Galeria Cultural; a segunda, a Galeria de Estudos, destina-se preferencialmente a públicos especializados e conta, além das exposições concebidas sistematicamente em torno de temáticas de pesquisa etnológica, com imagens e informações em audiovisuais

14. Para ter um panorama completo, ver $\mathrm{Mu}$ sée national des arts et traditions populaires: guide (Cuisenier \& Tricornot 1987).

15. Entre as iniciativas brasileiras nesta linha, chamo atenção para o caso do Museu da Cidade de Salto, no interior do Estado de São Paulo, em que foi estabelecido um museu sede, dois núcleos externos, constituídos por dois parques em torno de patrimônios históricos e natu- pode ser feito em relação às figuras 5 e 6$)$.

Quanto aos recortes das linhas de pesquisa do ATP, de que decorreram as grandes coletas de acervos entre 1937 e 1971, são explicados por Rivière \& Cuisenier (1972), num breve artigo de balanço: voltando-se, prioritariamente para a França rural pré-industrial, em vista da acelerada extinção de seus testemunhos materiais, elegeram-se como preferenciais as temáticas da agricultura e da criação de animais, como atividades básicas ${ }^{12}$. Várias enquetes e pesquisas neste sentido foram desenvolvidas pelo ATP ao longo dos anos, entre elas, apenas para exemplificar, uma enquete sobre a antiga agricultura, com base em questionário respondido por diretores de serviços agrícolas de departamentos administrativos franceses (1937-38), uma outra sobre o mobiliário rural, conduzida por uma equipe de antigos alunos de escolas de arte aplicada (1941-47) ou uma pesquisa programada desenvolvida por uma equipe pluridisciplinar de cerca de quarenta pesquisadores, organizada pelo CNRS /Conselho Nacional de Pesquisas Científicas), sobre A região de Aubrac: estudo etnológico, lingüístico, agronômico e econômico de um assentamento humano (1963-65), do qual decorreu uma extensa coleta de acervos de todas as ordens para o ATP.

A distribuição temática dos acervos pelas exposições, tanto na Galeria Cultural como na Galeria de Estudos ${ }^{13}$, dá-nos um panorama dos campos de atuação do Museu: a Galeria Cultural, dirigida ao grande público, propõe-se como sintese e apresenta, em sequência: um panorama da região natural correspondente à França (geografia física e humana, lingüística, etc.); o meio-ambiente no qual se implantaram as culturas; técnicas diversas relativas a atividades como a pesca, a criação de animais, a confecção de roupas ("da tosa à roupa"), da fabricação do vinho ("da vinha ao vinho") ou do pão ("do trigo ao pão"); costumes e ritos de passagem, e assim por diante. A Galeria de Estudos foi concebida para atender especialistas, estudantes, colecionadores. Enfim, aqueles que se interessam por determinados assuntos, podem encontrar, em exposição, seqüências de objetos sistematicamente dispostos em função de determinadas práticas culturais, como as atividades de colheita, caça e pesca, fabricação de instrumentos musicais, etc., etc ${ }^{14}$.

Para trabalhar museograficamente os acervos, Rivière propôs e realizou exposições que criam sistemas de articulação em torno de determinados temas e questões. Isto - dentro de uma tendência mais geral de nosso tempo - contrapôs-se às antigas exposições excessivamente classificatórias e tipológicas. Veja-se, como exemplo, a figura 6 , em que várias ferramentas e partes de instrumentos são dispostas de modo a permitir a compreensão da articulação existente entre elas, em função de uma atividade tradicional: a fabricação de certos instrumentos de cordas. Além disso, para dar conta de realizar exposições temáticas e pedagógicas - em geral seu propósito em termos de exposições - Georges Henri Rivière defendeu e incentivou o uso de audiovisuais, maquetes, modelos e qualquer outro recurso que auxiliasse na articulação dos objetos, que continuaram - é preciso frisar como documentos centrais das exposições. Sobre as técnicas no uso de recursos audiovisuais em museus, após elencar suas vantagens, ressalva: "a emissão visual e sonora dos aparelhos traz o risco, todavia, de prejudicar o ambiente dos objetos e modelos, os componentes mais importantes da exposição. Daí a necessidade de se realizar um isolamento acústico ou óptico dos campos a serem cobertos 
pelas emissões" (Rivière 1973: 29, grifos nossos).

A grande preocupação de Rivière com a comunicação nas exposições museológicas e os recursos de apoio para criar os desejados sistemas articulados, levou, muitas vezes, a uma interpretação errônea de alguns observadores superficiais, no sentido de que a pesquisa e o acervo já não teriam, talvez, na "linha Rivière", a mesma importância que teriam em outros tipos de museus. Grave engano: como já vimos até aqui, por tudo o que representaram os "museus Rivière" em termos de pesquisa, de coleta e documentação de acervos, marcaram justamente o contrário. Ampliaram-se - isto sim - as noções de acervo e de patrimônio, passando-se a valorizar, enquanto documentos de história e cultura, tipos de objetos que antes eram considerados de pouca relevância.

Se os museus de artes e tradições populares trouxeram novos tipos de acervos para dentro de suas sedes, os ecomuseus, além disto, foram responsáveis pela inclusão no âmbito dos trabalhos museológicos, de territórios inteiros, com seus patrimônios naturais e culturais, dizendo-se deles que são "museus do tempo e do espaço", expressão calcada pelo próprio Rivière ${ }^{15}$.

\section{Os ecomuseus e a preservação de bens culturais}

No início dos anos 1970, uma outra realização marcante - mais revolucionária que as anteriores - foi a criação, em Creusot-Montceau-Les Mines, do primeiro ecomuseu em área industrial ${ }^{16}$. Justamente por trabalhar uma área com inúmeros problemas sociais, desenvolveu-se bastante no sentido da militância política e foi colocado como um instrumento da população para resolução de seus problemas. Foi apresentado como "Museu do Homem e da Indústria" e propunha-se como "sem limites que não aqueles da comunidade a que ele serve" (Varine-Bohan 1973: 244). Defendia-se a tese do ecomuseu como instrumento de autogestão de uma comunidade. O caráter político e libertário do Ecomuseu do Creusol foi sempre muito frisado, exatamente por ser este o ponto forte de sua proposta. Entretanto, ele não foi estruturado e gerido sem referência aos testemunhos materiais, tal como tem sido tantas vezes interpretado. O trabalho proposto o foi em torno de um território e de um patrimônio, nunca se descuidando da contribuição científica que poderia dar, tendo sido, inclusive, pioneiro, na França, na área da arqueologia industrial ${ }^{17}$. Quando se falou em não recolher ao museu todo e qualquer bem cultural, deixando-os, enquanto e quando fosse o caso, em seu local de uso, não se estava retirando deles sua importância - como se tem, por vezes, entendido - e nem se estava abrindo mão da idéia de preservá-los.

“Todo objeto que mantém, para seu possuidor natural, seja um valor funcional, seja emocional, deve permanecer fisicamente em seu lugar e, a este título, fazer parte da coleção geral; todo objeto que perdeu tanto seu valor funcional como emocional e que representa um testemunho necessário à comunidade e à sua história ou de seu ambiente, deve ser recolhido e depositado nas reservas do museu, para ser ali conservado é utilizado".

(Varine-Bohan 1973: 245)

Pelo trecho acima pode-se perceber não só a importância que é dada aos objetos enquanto documentos, como também a especificidade de um contexto em que seja possível a preservação consciente de testemunhos materiais por seus rais, além de dez pontos de referência no espaço urbano. Cito este caso por conhecê-lo de perto: como museóloga do $\mathrm{Mu}$ seu Paulista/USP e na qualidade de assessora pude participar de sua equipe de concepção e implantação, sob a coordenação do arquiteto e museólogo Julio Abe Wakahara e ao lado da historiadora Anicleide Zequini Rossi, autora de uma tese sobre a história da cidade de Salto (1991) e do arquiteto Alcino Izzo Jr. Tratou-se de uma iniciativa da Prefeitura Municipal de Salto e fizeram parte da equipe, também e entre outros, $o$ jornalista e historiador local, Ettore Liberalesso e uma museó-loga da cidade, Thalma Di Lelli. Sobre o projeto e a implantação do Museu da Cidade de Salto, ver Rossi \& Barbuy (1992). Sobre outros casos brasileiros, consultar os anais do Primeiro encontro internacional de ecomuseus (1992).

16. Segundo Mathilde Bellaigue (1989: 164), "Georges Henri Rivière e Hugues de Varine foram os padrinhos ativos do ecomuseu da Comunidade Le Creusot-Montceau-les-Mines, cujo criador, diretor e inspirador até 1983 foi Marcel Evrard".

17. Um museu de sítio arqueológico que marcou, pouco antes, a área da arqueologia industrial, foi $o$ de Ironbridge Gorge, no interior da Inglaterra. 
18. Trata-se de um relatório elaborado por Max Querrien, que havia sido incumbido, pelo ministro da Cultura da França, de estudar e propor uma política global para o patrimônio, envolvendo uma espécic de curadoria: dos tombamentos aos programas de pesquisa, da conservação aos programas educativos.

19. A expressão netghbourbood museum, traduzida sempre como museu de vizinbança, poderia também equivaler a museu de bairro. Sobre o Museu de Anacostia, ver Kinard \& Nighbert (1972) e sobre uma avaliação de especialistas franceses a seu respeito, ver Hubert, Jubeaux \& Veillard, orgs. (1983). próprios proprietários e as boas relações entre estes e os gestores do ecomuseu, a ponto de ser permitido, à instituição, inventariar, como bens culturais, aqueles de propriedade particular. Mas isto exige um tal processo e uma tal consciência, em que os documentos não precisem ser recolhidos aos museus ou aos arquivos para serem preservados, que beira a utopia.

Mesmo na França, este tipo de idéia mostrou-se, ao longo do tempo, como de difícil realização. Mas o mais importante foi, na verdade, mostrar que qualquer objeto, construção, paisagem ou conhecimento poderia ter valor documental e que o desejo e o encargo de sua preservação poderiam ser expressos e assumidos pelos próprios grupos sociais envolvidos:

"Todo objeto, móvel ou imóvel, que se encontre no interior do perímetro da comunidade, faz moralmente parle do museu" (Varine-Bohan 1973: 244).

Querrien (1982: 62-63) 18 observou que "nascido na contradição, o ecomuseu nela vive. Sua veia patrimonial o impulsiona a inventariar, coletar, conservar. Mas seu verdadeiro patrimônio não é outro senão a memória coletiva, da qual emerge uma identidade que, em sua singularidade, quer-se no combate da história presente e na gestação do futuro. (...) Mas está mais preocupado com a 'preservação dos saber-fazer (savoir-faire)' do que com a 'museificação dos objetos' ". Ora, a preservação dos "saber-fazer", das técnicas, das práticas não pressupõe, necessariamente, a preservação de seus suportes materiais? A compreensão de um dado universo sócio-cultural, desenvolvido em torno de determinadas atividades, tal como propõem os ecomuseus, necessitará, por certo, da compreensão de todo um mundo material. E para isto será necessário preservá-lo.

Apesar disto, é verdade que há linhas de trabalho que tendem a eliminar a preservação de acervos como uma de suas incumbências ou necessidades, limitando-se à organização de bancos de dados sobre o patrimônio local. É o caso dos neighbourhood museums americanos, em especial o primeiro deles, o de Anacostia, Washington, criado em 196719. Sempre citados pelos próprios especialistas franceses como "parentes próximos" dos ecomuseus, eles o são, por certo, no aspecto do trabalho comunitário e social que desenvolvem mas a questão dos acervos ou não-acervos continua suscitando polêmica.

Como estrutura destinada a organizar exposições pedagógicas sem acervos, difundem-se, no Canadá, os chamados "centros de interpretação", como por exemplo, o Centro de Interpretação do Porto ov o Centro de Interpretação da Cidade, ambos na capital de Québec. Podem ser considerados como derivações dos ecomuseus. Neles, entretanto, embora sejam utilizados, eventualmente, documentos materiais, não há compromissos com a produção de conhecimento em torno de acervos e, muito menos, com sua preservação. Mas os centros de interpretação são colocados estritamente como instrumentos didáticos; não são museus e nem pretendem ser.

Ecomuseus: "museus de sociedade"

A ênfase dada à função social dos ecomuseus, apesar de muito justa e procedente, acabou servindo a distorções de vários tipos no entendimento que se passou a ter, pelo mundo afora, a respeito do que eles seriam. Constituiram-se 
ecomuseus como se fossem uma agremiação qualquer, um partido político ou até um posto de assistência social. Um fórum qualquer para reuniões comunitárias. Por melhor que sejam as intençōes, não se trataria mais, então, de trabalhos museológicos.

Assim, é importante fazer notar que os primeiros ecomuseus - os de parques regionais, como vimos acima - não surgiram informalmente, nascidos da vontade de uma pequena comunidade idealista no interior da França (sendo esta, muito comumente, a imagem que se faz) e sim como conseqüência de uma política oficial.

É verdade que, ao longo do tempo, vários ecomuseus foram criados sobre bases associativas e representam, hoje, uma gama de ecomuseus denominados comunitários, colocando-se, em muitos casos, como centros de resistência cultural. Fundamentam-se, juridicamente, numa lei francesa de 1901 , criada para facilitar a livre formação de associações em geral, sem fins lucrativos ${ }^{20}$. Entretanto, os ecomuseus comunitários têm sido muitas vezes alvo de críticas pela falta de critérios com que são conduzidos por leigos. Ademais, boa parte deles, assim que atinge um certo grau de desenvolvimento, acaba por integrar-se aos sistemas oficiais, institucionalizando-se.

Mas assim como os primeiros, até hoje a maior parte dos ecomuseus é organizada dentro de programas oficiais, seja de nivel nacional, regional ou local. Aliás, assim começa a Définition évolutive de l'écomusée, de Georges Henri Rivière:

"o ecomusev é um instrumento que um poder e uma população concebem, fabricam e exploram juntos. O poder, com os especialistas, as facilidades e os recursos que fornece. A população, segundo suas aspirações, seus saberes, sua capacidade de análise" (Rivière 1983).

Na França, durante a década de 1980, o patrimônio cultural foi oficialmente tratado como uma ferramenta para o desenvolvimento, como atesta o estudo dirigido por Isabelle Van de Walle: partindo da idéia de que "o patrimônio está no centro de um processo de desenvolvimento local, que se apoia na valorização do conjunto de potencialidades de um território, potencialidades físicas, culturais, humanas, econômicas" (Van de Walle 1987: 91, implementaram-se amplas políticas oficiais, envolvendo mais de um ministério (Ministérios da Agricultura, da Cultura, do Meio Ambiente e a Fundação de Françal, visando estabelecer programas de reviłalização e desenvolvimento em torno de patrimônios locais, programas estes em que museus e ecomuseus tomaram parte, além de inúmeras outras instituições e organizações.

De qualquer modo, formam-se museus e ecomuseus com os mais diversos fins. São comuns, por exemplo, casos de museus locais e regionais ou de ecomuseus que se constituem em torno de um patrimônio mas não o trabalham como documento, como objeto de estudos, nem mesmo no tocante à sua carga simbólica; coloca-se o patrimônio, nestes casos, apenas como símbolo de determinadas causas, pretexto para militâncias de todos os tipos. Ironicamente, agindo assim, está-se retornando, por caminhos tortos, ao objeto-fetiche, que tanto se combateu:
20. O texto legal de $1 /$ 7/1901 foi reproduzido, entre outros, no vademecum culturel juridique (França [1993]: 57-63). 
"Um programa de ecomuseu - afirma Hubert (1985: 189) - mobiliza uma parte importante da população e intensifica a vida social, o risco do ecomuseu comunitário residindo, precisamente, em nunca ir além desse papel. Pois é a ausência de dimensão científica, na maior parte dos processos, que destila desvios e contradições".

Em sentido inverso, num outro tipo de caso, apropriações indevidas promoveram a criação de ecomuseus sem compromissos ou envolvimento com as respectivas populações e, nestes casos, o termo ecomuseu acaba mascarando tendências passadistas e mitificadoras, inclusive com conotações "micronacionalistas" (Hubert 1985: 187-188).

Eis aí a problemática central dos ecomuseus: o limite entre o caráter revolucionário ou conservador da construção de identidades culturais.

Ainda seguindo o fio do desenvolvimento dos ecomuseus franceses, vejamos como eles se apresentam, mais recentemente, para o grande público, através de algumas frases encontradas em folhetos de divulgação:

"Avante memória"

(slogan criado em 1986 e encontrado em mais de um folheto, como no da Federação dos Ecomuseus e dos Museus de Sociedade, ainda em circulação em 1993).

"Visite os ecomuseus e os museus de sociedade para compreender e guardar na memória aquilo que se transmite e se transforma à sua volta".

(Folhelo da Federação dos Ecomuseus e dos Museus de Sociedade, c. 1986, ainda em circulação em 19931.

"Objetos, ofícios e gestos, sítios industriais e paisagens, história social, culturas de ontem e de hoje.

(lb.).

"Um passado infinitamente presente"

(Folheto do Ecomuseu de Marquèze, Grande Lande, c.1986, ainda em circulação em 19931.

"A grande aventura marítima e industrial de Saint-Nazaire começou em meados do século XIX (...). Hoje como ontem, a indústria nazairiana demonstra uma cultura técnica de alto nível e capacidades de inovação e adaptação. (...) Mas a aventura continua (...). É esta aventura que o ecomuseu se propõe estudar e traduzir (...) e com a colaboração de todos os que definem juntos os aspectos multiformes e contraditórios de uma mesma realidade e de seu futuro".

(Folheto do Ecomuseu de Saint-Nazaire, 1988).

"Aonde, diabos, esta máquina do tempo vai me levar?

Saint-Nazaire, terra e mar, ontem, hoje e amanhã"

(capa do porta-folhetos do Ecomuseu de Saint-Nazaire, 1988).

As frases acima introduzem todas o passado - através da memória como elemento enzimático, ativo sobre o presente e/ou sobre o futuro. De fato, este pode ser considerado, talvez, o ponto central da filosofia dos ecomuseus: a afirmação, através da memória, de uma identidade cultural, que permitiria dar um rumo mais legítimo ao presente; tornaria mais claro, para uma coletividade, que caminhos tomar. No início dos anos 80 foi enfatizada a relação dos ecomuseus com as identidades (e o direito à diferença), num momento de crise (chegaram a ser chamados de "museus da recessão"I. E isto, inclusive, por questões de política oficial do governo Miterrand: Max Querrien (1982), no relatório citado acima, 
formulou uma reflexão neste sentido, com a preocupação em criar uma diferenciação em relação ao governo anterior/Giscard d'Estaingl, que havia tratado a questão do patrimônio de forma bastante convencional, como política de preservação de monumentos, por assim dizer. É o que pondera Poulot 11994: 73), assinalando, inclusive, que Les lieux de mémoire, obra dirigida por $P$. Nora (1984/86), foi organizada nesta mesma época e com preocupação de mesma ordem, de refletir sobre a identidade francesa e a memória coletiva.

$\bigcirc$ problema da identidade nos museus foi abordado com acuidade por Ulpiano T. Bezerra de Meneses, num artigo cuja leitura pode trazer inquietação, justamente por questionar um "dogma". Apontando para uma perda geral de sentido crítico, mostra que a identidade passou a ser considerada, desde os anos 60, no seio das ideologias difundidas nos museus (como em outros campos), como "uma substância, quintessência de valores e qualidades a priori positivos, imunes a qualquer crivo. E o museu como seu santuário" (Meneses 1993: 208). O autor não nega o saldo positivo que a política em torno das identidades culturais trouxe num quadro geral de militâncias nos museus. Mas assinala que o dogmatismo em torno de um pretenso caráter salvador da noção/sentimento de identidade cultural pode ser bastante prejudicial quando se perde a capacidade de análise crítica.

Os ecomuseus sempre trabalharam muito acentuadamente em torno do conceito de identidade, a começar já por seus antecessores los museus regionaisl, embora em diferentes direções e com diferentes conotações ao longo do tempo e do espaço. A própria Definição evolutiva do ecomuseu, de Georges Henri Rivière (1983) ${ }^{21}$, conhecida e repetida em coro por toda uma gama de museólogos no mundo todo, traz em seu bojo a noção de identidade, quando define o ecomuseu como espelho para auto-reconhecimento de uma população. É a isto que mais se tem apegado a maioria mas é preciso ler o texto de Rivière todo, prestando atenção à evolução de idéias, não esquecendo os outros definidores, que além do espelho compõem a complexidade do ecomuseu - e da noção de identidade como processo dinâmico: instrumento conjunto de um poder e de uma população; expressão do homem e da natureza; expressão do tempo; interpretação do espaço; laboratório de estudos; conservatório do patrimônio natural e cultural; escola.

É verdade que, ao se apresentar como síntese e espelho de identidade, esse tipo de museu pode tender a simplificar questões e "desproblematizar" problemas históricos mas a proposta sempre foi, ao contrário, fazer deles centros dinâmicos de reflexão intelectual e política. Sobre o conservadorismo (ou não) da noção de identidade cultural vale acrescentar que esses museus (que geralmente trabalham em linhas de antropologia histórical, muitas vezes formalmente designados como museus de identidade, passaram mais tarde a se chamar museus de sociedade (de interação social e/ ou tendo a sociedade como objeto de estudos e campo de atuaçãol, justamente porque a tônica da identidade cultural teria raízes muito próximas das que desencadearam e desencadeiam os racismos e outros fatores de segregações sociais. A expressão museus de sociedade é utilizada oficialmente para designar, na França, inclusive administrativamente, museus de etnografia regional, ecomuseus e afins. Seu sentido foi definido por Claude LéviStrauss como sendo o de "ensinar às pessoas, especialmente às crianças e aos
21. O mesmo texto, elaborado em 1980 , foi publicado, por vezes com pequenas modificações, em vários veículos, tais como o jornal Ecomusée informations (1983: 1), do Creusot; na antologia reunida ao final do livro de Dagognet (1984: 168-169); e no n. 148 da revista $M u$ seum (1985), sobre os ecomuseus. 
22. Sobre o trabalho interdisciplinar na formação do Museu da Bretanha, ver Veillard (1972). adolescentes, como melhor situar-se na sociedade em que vivem" (Lévi-Strauss 1992: 1681.

Mais recentemente, criou-se, no Canadá, a expressão museu de civilização (ou das civilizações), que, pouco esclarecedora à primeira vista, corresponde à solução conceitual a que se chegou na evolução dos antigos "museus de identidade", pretendendo continuar em sua linha de atuação social localizada mas em plena sintonia com a era da "globalização". Isto pode parecer paradoxal, por um lado e, por outro, pode reconduzir, de certo modo, aos museus universais, mas assim se apresentam:

"Um museu nacional de história humana desempenha um papel particular (...). Tende a definir nossa identidade cultural e nosso próprio país, incentivar os canadenses a terem orgutho de sua cultura, dá a conhecer ao mundo a originalidade do Canadá e mostra como povos de diferentes culturas moldaram o país e foram por ele moldados.

(...)

Hoje acessível ao mundo todo, o Museu Canadense das Civilizações (él o microcosmo da aldeia global. (...) O pensamento deste grande pioneiro canadense das comunicações e mídias, que foi Marshall Mcluhan teve tal influência na concepção do musev, que merece ser considerado como um dos mentores do projeto".

(MacDonald \& Alsford (1989: 2-4), sobre o Museu das Civilizações, na cidade de Hull (Québec), Canadá).

"O complexo do Museu constitui uma instituição cultural e educativa que tem, entre suas vocações, as de difundir a História do Québec e de estabelecer comparações com outras maneiras de ver ou dé fazer pelo mundo afora".

(Marie-José Rivières (1991: 1), sobre o Museu da Civilização, na cidade de Québec (Québec), Canadá).

Interdisciplinaridade/Interação

Desde 1980, quando o Comitê de Museologia do Conselho Internacional de Museus (ICOFOM-ICOM) definiu, formalmente, o caráter interdisciplinar da Museologia (Museological Working Papers 1980), muitos fios têm-se cruzado (e emaranhadol na compreensão do sentido dessa interdisciplinaridade.

Nos ecomuseus e em vários museus regionais franceses, a interdisciplinaridade foi praticada como decorrência de uma necessidade de fazer interagir diferentes especialistas e conhecimentos para trabalhar, em toda a sua complexidade, uma dada cultura.

Assim, História, Arqueologia e Antropologia regionais são apresentadas como disciplinas de base de museus como, por exemplo, o Museu da Bretanha, em Rennes, observando-se que se trata de uma região rica em sítios arqueológicos, com uma cultura e uma história bastante particulares ${ }^{22}$.

Quanto aos ecomuseus, além da interação das disciplinas acima, seria comum intervirem também especialistas em ciências da natureza, em técnica e tecnologia, além de portadores de conhecimento não acadêmico, detido por aqueles que viveram e agiram num dado tempo/espaço, ao qual se dedica o ecomuseu. A depender da área de atuação do ecomuseu, um antigo minerador, um chapeleiro ou um ex-tripulante de um submarino, por exemplo, poderá atuar junto ao ecomuseu, na qualidade de membro da comunidade envolvida, que traz também seu saber ao conjunto de conhecimentos que interagem para a formação 
e a atuação do ecomuseu ${ }^{23}$.

Houve uma espécie de fórmula ideal, proposta por Rivière - e dificilmente aplicada na íntegra - em que os ecomuseus seriam conduzidos pela ação conjunta e solidária de três comitês: o de gestão (administradores municipais ou regionais), o de usuários (membros da comunidade envolvida) e o científico (acadêmicos pertencentes aos quadros de universidades próximas, estudiosos de questões implicadas na proposta do ecomuseu) (cf. Barbuy 1989).

Território/Comunidade

A partir da primeira fase dos ecomuseus - a dos parques regionais - foi alavancada a idéia-chave do envolvimento de todo um território /de onde teria surgido, inclusive, o termo eco-museu, museu dedicado a um território, seu meioambiente, seja natural, rural, urbano e/ou industrial). Mas a própria idéia de território pode ser tomada em seu sentido mais espacial ou não. Há uma tendência em se conferir ao termo território, um sentido mais antropológico, ou seja, aquele de um território construído por uma dada população e a ela pertencente, com ela identificado (cf. Davallon 1986: 105-114).

Mas o âmbito espacial é, na verdade, o diferenciador mais visível dos ecomuseus; é isto que os torna diferentes às vistas do visitante comum: o Ecomuseu de Rennes (La Bintinais), por exemplo, constituiu-se nos domínios de uma fazenda do século XVII, preservada num meio hoje totalmente urbanizado (Fig. 9) ${ }^{24}$; o Ecomuseu de Saint-Nazaire teve sua sede instalada dentro da área portuária. Ambos foram criados em 1988, e correspondem à geração mais recente de ecomuseus franceses (uma quarta geração). $O$ primeiro, na linha dos ecomuseus de culturas rurais, dedica-se aos modos de vida ligados à cultura rural da região de Rennes, marcada, "antes de mais nada, pelo ritmo da vida quotidiana, regulada pelo desenrolar das estações e a sucessão dos trabalhos agrícolas" (trecho do texto de fechamento da exposição central, que, intitulado Vivre au pays de Rennes, indica o sentido de síntese da exposição permanente instalada na casa-sede da fazenda da Bintinais). Seus grandes temas são "o desenvolvimento demográfico e urbano de Rennes e de sua região; as gerações de proprietários, fazendeiros e empregados, ligados à Bintinais; a vida quotidiana (cozinha, lazer, linguagem, vestimentas e arranjos de espaços interiores; a história das produções agrícolas e as técnicas, do Antigo Regime aos nossos dias" (cf. Clarke, Maillard \& Veillard 1991: 3) (Figs. 10) ${ }^{25}$. O segundo caso, o Ecomuseu de Saint-Nazaire, na linha dos ecomuseus de culturas industriais, dedica-se a uma cidade portuária, de população majoritariamente migrante, vinda em função da indústria naval e, hoje, também aeroespacial. Quase totalmente destruída durante a II Guerra Mundial, ao ser reconstruída, Saint-Nazaire seguiu um plano urbanístico que promovia a separação entre a zona urbana propriamente dita e a zona portuária. O ecomuseu foi instalado em função de uma nova política, que visava a religação da cidade com seu porto (cf. Saint-Nazaire 1985).

Alguns ecomuseus, que levaram à frente a idéia de um "espalhar-se" pelo território (éclatement), implantaram as chamadas antenas, centros museológicos que, interligados a uma sede-síntese, tratariam de temas específicos, formando uma rede espalhada pelo território ao qual o ecomuseu se dedica (por exemplo,
23. Observe-se que o museu e a Museologia são vistos, desse modo, como interdisciplinares mas isto não se estenderia para o museólogo, como tão freqüentemente se tem entendido.

24. Sobre a história da Fazenda da Bintinais e sua transformação em ecomuseu, ver Hubert, Maillard \& Veillard (1987).

25.A Bintinais não guarda acervos em reservas mas a exposição não prescinde deles. $\mathrm{E}$, além disso, é um ecomuseu anexo ao Museu da Bretanha: "no local, não há coleções a gerir, não há reservas: esta tarefa continua fazendo parte das missões do Museu da Bretanha" (Hubert 1991: 53). 
uma antiga escola pode se transformar numa antena - um museu - para pesquisas, coletas de acervo, exposições e todo tipo de atividade museológica em torno da história daquela escola ou, de modo mais amplo, da pedagogia naquela região e assim por diante).

Sentido de atualidade

Alguns ecomuseus seguiram explicitamente pelo caminho da nostalgia passadista. Entretanto, como princípio, o ecomuseu foi proposto como instrumento permanente de ligação entre o passado e questões candentes de atualidade social.

A grande revolução deste tipo de museologia foi, na verdade, a propulsão dos museus em direção ao tempo presente e também ao futuro. Em sua concepção, o passado deixa de ser uma espécie de "tempo forte", mitificado e paralisado em uma existência estanque de algo que não se relaciona com a atualidade para ser abordado em perspectiva, sendo-the conferida uma noção de dinâmica que o inter-relaciona com o presente e faz tudo pertencer a um mesmo e complexo processo histórico (ou antropológico-histórico, essencialmente). Mesmo no campo simbólico, os objetos do passado deixam de ser simplesmente reificados, congelados e a seguir reverenciados como algo distante e intocável para reassumir um papel dinâmico no sistema simbólico do tempo presente.

Hoje, num exemplo do que seria um ecomuseu de última geração, é com o sentido da atualidade que, em suas áreas ao ar livre, o Ecomuseu de Rennes, na antiga fazenda da Bintinais, mantém a criação de espécimes em extinção, animais e vegetais (Fig. 11 l, no sentido não de passadismo mas de preservação ecológica: em função dos objetivos de produtividade que têm orientado as atividades agropecuárias, várias raças de animais e tipos de plantas têm sido deixados de lado e passa, por isto, a haver a preocupação com sua extinção e com o conseqüente empobrecimento do patrimônio genético do planeta. $O$ tema, dos mais atuais, é ali tratado cientificamente e amplamente explorado em atividades educativas.

In memoriam

A Waldisa Rússio Camargo Guarnieri. 


\section{BIBLIOGRAFIA}

ABREU, Regina. História de uma coleção: Miguel Calmon e o Museu Histórico Nacional.Anais do Museu Paulista: história e cultura material, São Paulo,n.sér. v.2, p.199-233, 1994.

ALEXANDER, Edward P. Open-air or outdoor museums. In: ALEXANDER, Edward P. Museums in motion: an introduction to the history and functions of museums. Nashville: American Association for State and Local History, 1978. p.84-86.

BAEHRENDTZ, Nils Erik, BIÖRNSTAD, Ingmar Liman, PALM, Per Olof. Skansen: a stock-taking at ninety. Museum, Paris, v.34, n.3, p.173-178, 1982.

BALASSA, Iván. Agriculture traditionnelle et histoire de l'agriculture dans les musées. Museum, Paris, v.24, n.3, p.145-149, 1972.

BARBUY, Heloisa.A experiência dos ecomuseus. Folha de S.Paulo, São Paulo, 26 jan. 1989, p.4.

BARBUY, Heloisa. A Exposição Universal de 1889: visão e representação na sociedade industrial. São Paulo, 1995, 170p. Dissertação (Mestrado) - Departamento de História, Faculdade de Filosofia, Letras e Ciências Humanas/Universidade de São Paulo.

BELLAIGUE, Mathilde. Uma nova visão do passado. Memória, São Paulo, anoV, n.19, p.74-77, jul.-ago.1993 (entrevista a Heloisa Barbuy).

BELLAIGUE, Mathilde. Georges Henri Rivière et la genèse de l'écomusée de la Communauté Le Creusot-Montceau-les-Mines. In: LA MUSEOLOGIE selon Georges Henri Rivière. Paris: Bordas/ Dunod, 1989. p.164-165.

CIRESE, Alberto Mario. Le operazioni museographiche come metalinguaggio (1967). In: CIRESE, Alberto Mario. Oggetti, segni, musei: sulle tradizioni contadine. Torino: Einaudi, 1977. p.33-56.

CLARKE,Alison, MAILLARD, Jean-Luc,VEILLARD,Jean-Yves.L'écomusée du pays de Rennes. Rennes: Ouest-France, 1991.

COLLET, Isabelle. Les premiers musées d'ethnographie régionale en France. In: MUSEE NATIONAL DESARTS ETTRADITIONS POPULAIRES.Muséologie et Ethnologie. Paris: Réunion des musées nationaux, 1987a. p.68-99.

COLLET,Isabelle.Le monde rural aux expositions universelles de 1900 à 1937.In:MUSEE NATIONAL DESARTS ETTRADITIONS POPULAIRES.Muséologie et Etbnologie. Paris, Réunion des musées nationaux, $1987 \mathrm{~b}$. p.100-139.

CUISENIER,Jean,TRICORNOT,Marie-Chantal de.Musée national des arts et traditions populaires: guide. Paris: Réunion des musées nationaux, 1987.

DAGOGNET, François. Le musée sans fin. Seyssel: Champ Vallon, 1984. (Collection Milieux). 
DAVALlon, Jean. Philosophie des écomusées. In: DAVALLON, Jean (Dir.) Claquemurer tout l'univers pour ainsi dire: la mise en exposition. Paris:Centre de Création Industrielle/Centre Georges Pompidou, 1986. p.105-126.

DIAS, Nélia. Le Musée d'Etbnograpbie du Trocadéro (1878-1908): Anthropologie et Muséologie en France. Paris: CNRS, 1991.

FRANÇA (Ministère de la culture et de la francophonie). Vademecum culturel juridique. Paris: Imprimerie nationale, [1993].

GAULUPEAU, Yves. P. Commepatrie: en France entre 1850 et 1950. Roven:I.N.R.P.- Musée national de l' Education, 1988.

GESTIN,Jean-Pierre. Muséologie et Parcs naturels. In:LA MUSEOLOGIE selon Georges Henri Rivière. Paris: Bordas/Dunod, 1989. p.155-163.

HUBERT, François, JOUBEAUX,-Hervé, VEILLARD, Jean-Yves (Orgs.). Découvrir les écomusées. Rennes: Musée de Bretagne-Ecomusée Les Bintinais, 1983.

HUBERT, François, MAILLARD, Jean-Luc, VEILLARD, Jean-Yves. Ecomusée du pays de Rennes: La Bintinais. Rennes: Ecomusée du pays de Rennes, 1987.

HUBERT, François. L'Ecomusée du pays de Rennes à la ferme de la Bintinais. In:Le guide des musées du Grand Ouest. La Chasse-Marée/ArMen: Presse de l'Université Rennes 2, 1991.p.53-56.

HUBERT, François. Les écomusées en France: contradictions et déviations. Museum, Paris, n.148, p.186-190, 1985.

KINARD, John R., NIGHBERT, Esther.Le "musée de voisinage" d'Anacostia, Smithsonian Institution, Washington, D.C. Museum, Paris, v.24, n.2, p.103-109, 1972.

L'EXPOSITION de Paris, 1889. Sceaux: Imprimerie Charaire \& Fils, 1888-1890. 4v.

LA MUSEOLOGIE selon Georges Henri Rivière. Paris: Bordas/Dunod, 1989.

LEVI-STRAUSS, Claude. Qu'est-ce qu'un musée des arts et traditions populaires? Le Débat, Paris, n.70, p.165-173, mai/août 1992 (entrevista a Isac Chiva).

MACDONALD, George F, ALSFORD, Stephen. Un musée pour le village global. Hull, Québec: Musée canadien des civilisations, 1989.

MENESES, Ulpiano T. Bezerra de. A problemática da identidade cultural nos museus: de objetivo (de ação) a objeto (de conhecimento).Anais do Museu Paulista: história e cultura material, São Paulo, n.sér. n.1, p.207-222, 1993.

MORINEAUX,Yves. Les parcs naturels régionaux. Paris: La Documentation Française, 1982. (Notes et études documentaires, 4439-4440). 
MUSEOLOGICAL WORKING PAPERS - MUWOP, n.2, 1980.

MUSEUM, Paris, n.148, 1985. ("Images de l'écomusée").

NORA, Pierre (Dir.) Les lieux de mémoire. Paris: Gallimard, 1984/86. 5v.

ORY, Pascal. Georges Henri Rivière fondateur du Musée des arts et traditions populaires. In: LA MUSEOLOGIE selon Georges Henri Rivière. Paris: Bordas/Dunod, 1989.

POULOT, Dominique. Identity as self-discovery: the ecomuseum in France. In: SHERMAN, Daniel, ROGOFF, Irit (Eds.). Museum culture: histories, discourses, spectacles. London: Routledge, 1994.

PRIMEIRO encontro internacional de ecomuseus. Rio de Janeiro, 1992. Anais. Rio de Janeiro, Secretaria Municipal de Cultura,Turismo e Esporte, 18-23 maio 1992.

QUERRIEN, Max.Les écomusées. In:QUERRIEN, Max.Pour une nouvelle politique du patrimoine: rapport au ministre de la culture. Paris: La Documentation Française, 1982.

RICHARD, Jules. L'Exposition d'agriculture. L'Exposition de Paris, 1889. Sceaux, v. 1/2,n.18, p.142144, 29 juin 1889.

RIVIERE, Georges Henri, CUISENIER, Jean. Le Musée des arts et traditions populaires, Paris. Museum, Paris, v.24, n.3, p.181-184, 1972.

RIVIERE, Georges Henri. Rôle du musée d'art et du musée de sciences humaines et sociales. Museum, Paris, v.25, n.1/2, p.26-44, 1973.

RIVIERE, Georges Henri. Définition évolutive de l'écomusée. Ecomusée informations de la Communauté Le Creusot Montceau les Mines, Le Creusot, n.8, p.1, déc. 1983.

RIVIERE, Georges Henri. Le musée de plein air des Landes de Gascogne. MUSEE NATIONAL DES ARTS ET TRADITIONS POPULAIRES. Muséologie et Etbnologie. Paris: Réunion des musées nationaux, 1987 . p. $260-271$.

RIVIERES, Marie-José. Musée de la civilisation. Québec: Musée de la civilisation, 1991.

ROSSI, Anicleide Zequini. O quintal da fábrica. Campinas, 1991, 280p. Dissertação (Mestrado) Departamento de História, Instituto de Filosofia e Ciências Humanas/ Universidade Estadual de Campinas.

ROSSI,Anicleide, BARBUY, Heloisa. Museu da Cidade de Salto: projeto e implantação. Boletim do Centro de Memória UNICAMP, Campinas, v.4, n.7/8, p.53-64, jan.-dez.1992.

SAINT-NAZAIRE, Ecomusée: Centre de recherche et de découverte de l'estuaire. Saint-Nazaire, mai 1985, dat. 
SEBILLOT, Paul. L'Ethnographie traditionnelle et les musées cantonaux. Annuaire des musées cantonaux, p.9-20, 1886-1887.

SEBILLOT, Paul, LANDRIN, Armand. Instructions sommaires relatives aux collections provinciales d'objets ethnographiques. In:La tradition en Poitou et Charentes. Niort, 1896. Congrès. Paris/ Niort: s.n., 1897. p.465-475.

VAN DE WALLE, Isabelle (Dir.) Le patrimoine local, un outil du développement: rapport d'étude. Paris:Association nationale pour le développement local et les pays, 1987.

VARINE-BOHAN, Hugues de. Un musée "éclaté": le Musée de l'homme et de l'industrie Le CreusotMontceau-les-Mines. Museum, Paris, v.25, n.4, p.242-249, 1973.

VARINE-BOHAN, Hugues de. $A$ experiência internacional. São Paulo: Faculdade de Arquitetura e Urbanismo da Universidade de São Paulo/Instituto do Patrimônio Histórico e Artístico Nacional, 1974.

VEILLARD,Jean-Yves. Problèmes du musée d'histoire à partir de l'expérience du Musée de Bretagne, Rennes. Museum, Paris, v.24, n.4́, p.193-203, 1972.

VEILLARD, Jean-Yves. Histoire et formation des collections du Musée de Bretagne: des parcours révélateurs. In: MUSEE NATIONAL DES ARTS ET TRADITIONS POPULAIRES. Muséologie et Ethnologie. Paris: Réunion des musées nationaux, 1987. p.248-255. 


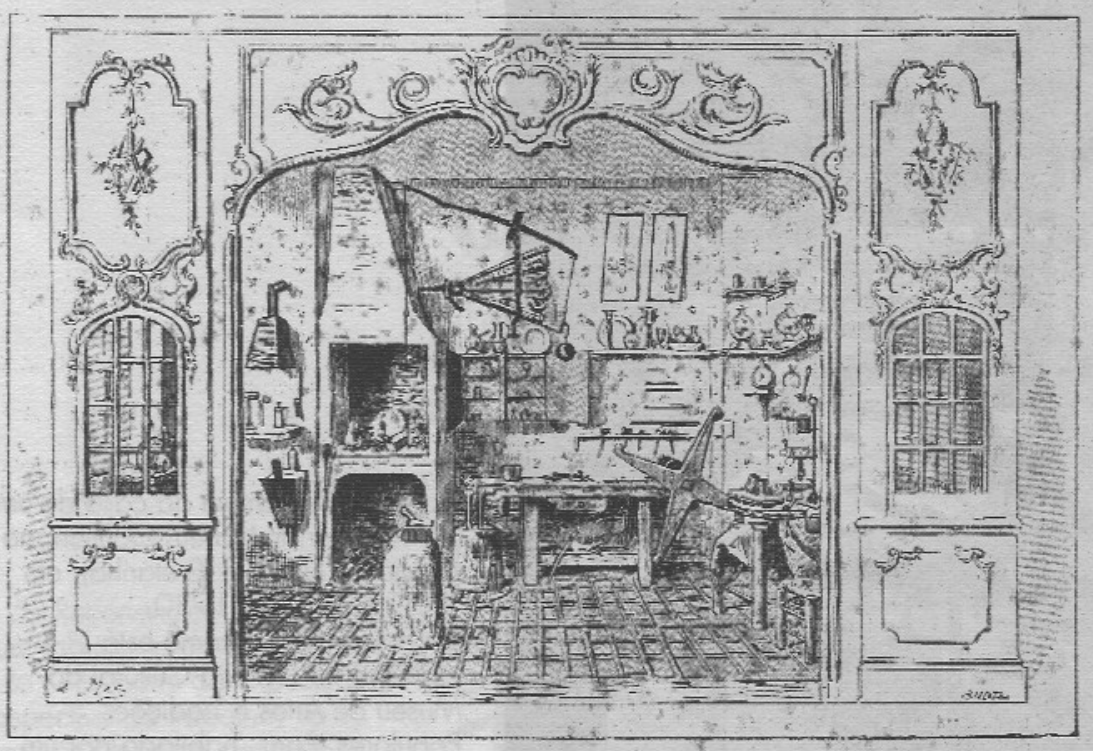

Fig. 1 - Reconstituição do interior de uma casa camponesa do século XVIII, parte da exposição retrospectiva do trabalho, na Exposição Universal de 1889. In: L'Exposition de Paris, 1889 , v. 3/4, p. 232.

Biblioteca do Museu Paulista/USP

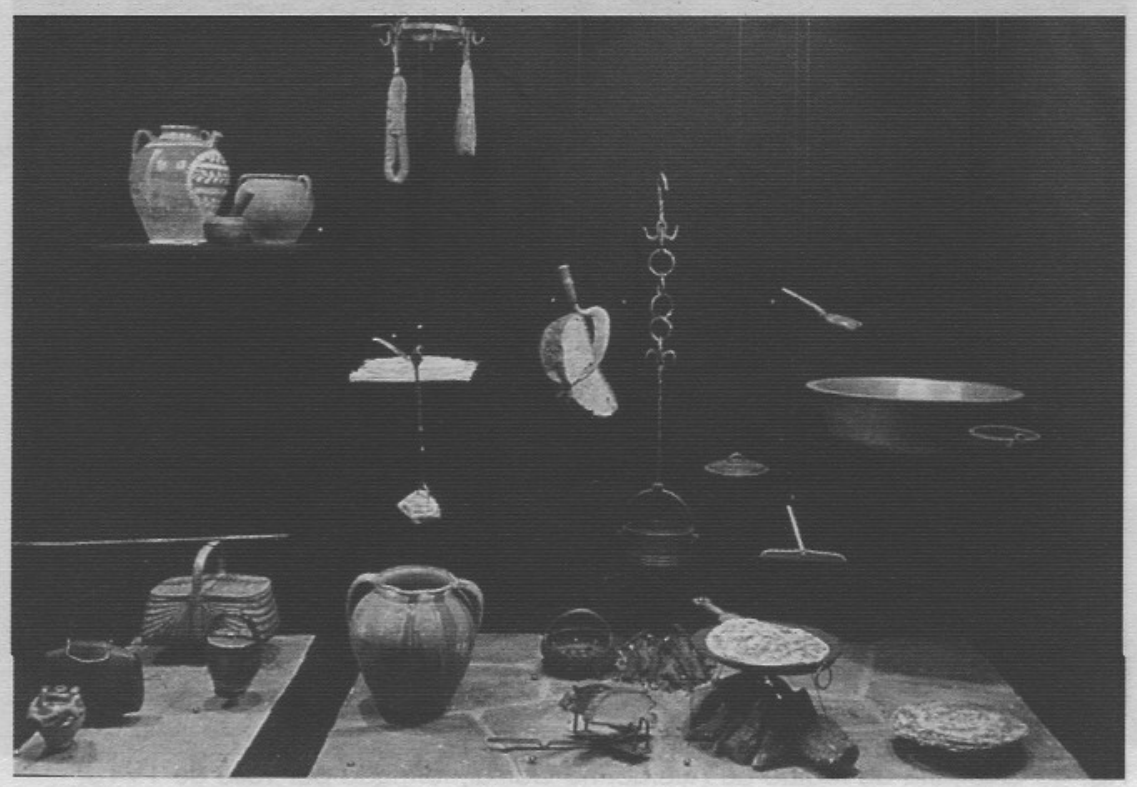

Fig. 2 - Conjunto sistemático de objetos relativos à alimentação em meio rural, em exposição no Museu de Artes e Tradições Populares, Paris.

Copyright Réunion des musées nationaux 


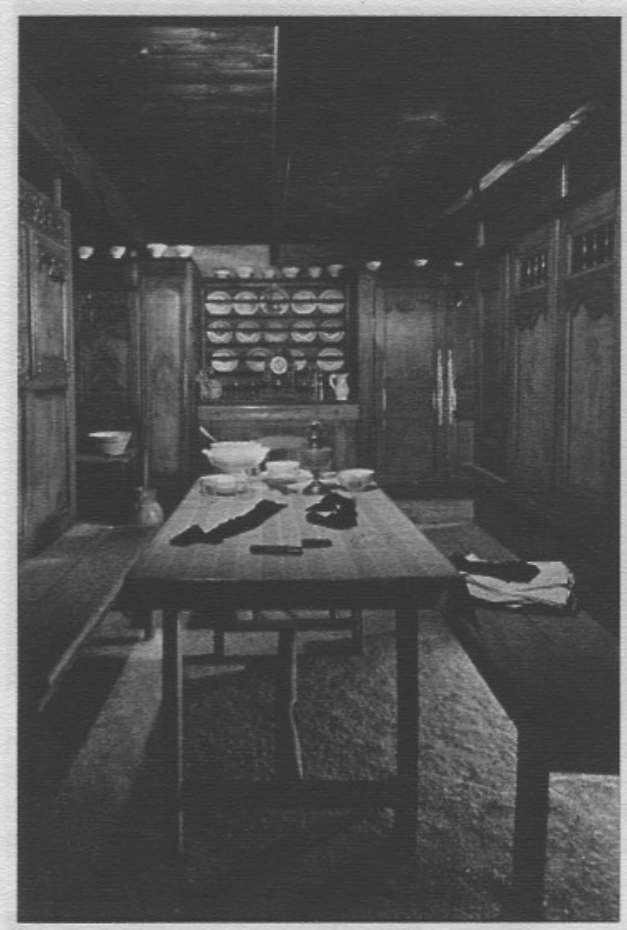

Fig. 3 - Sala-comum da casa de um artesão, construída em Goulien, na região de Finistère (Bretanha), em 1852 e que, em 1930 encontrava-se tal como está exposta, na Galeria Cultural do Museu de Artes e Tradições Populares, Paris, habitada por um casal (pedreiro e costureira) e outros familiares.

Copyright Réunion des musées nationaux

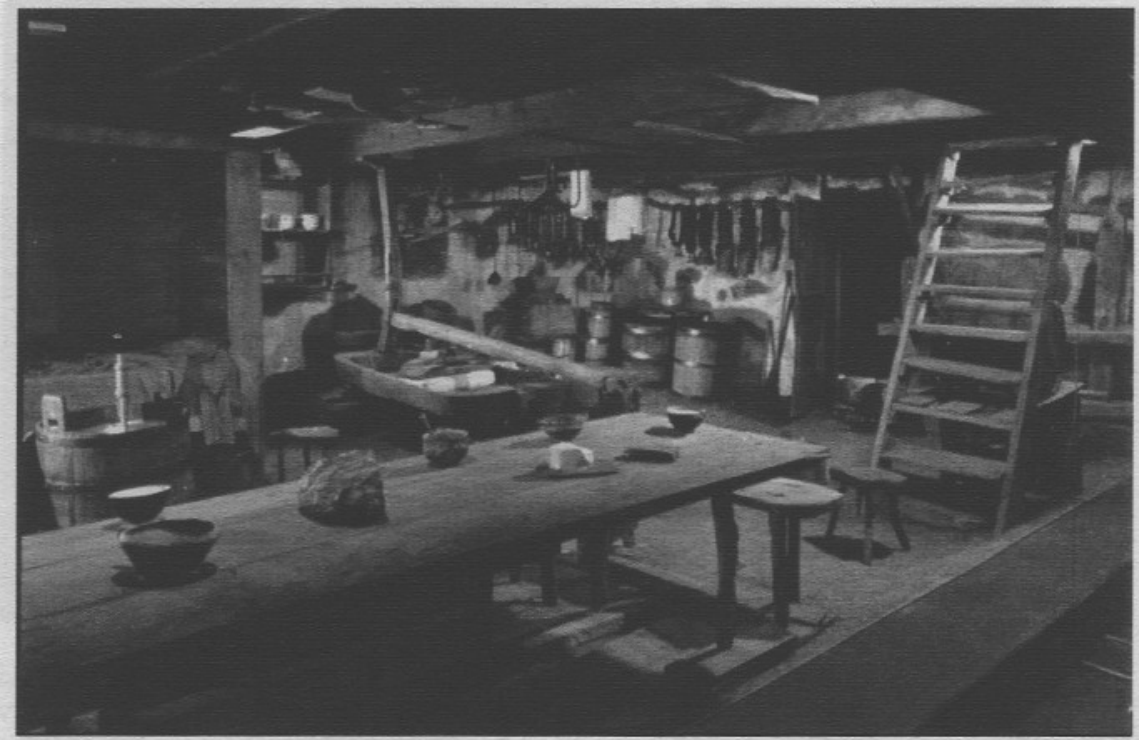

Fig. 4 - Queijaria da região de Aubrac, no Cantal, formada por volta de 1910, exposta na Galeria Cultural do Museu de Artes e Tradições Populares, Paris. A região é identificada com a fabricação do queijo, como atividade que permeia toda a cultura local.

Copyright Réunion des musées nationaux 
Fig. 5 - Reconstituição da oficina de um fabricante de alaúdes do século XVIII, parte da exposição retrospectiva do trabalho, na Exposição Universal de 1889. In: L'Exposition de Paris, $1889 \mathrm{v}$. 3/4, p.237.

Biblioteca do Museu Paulista/USP
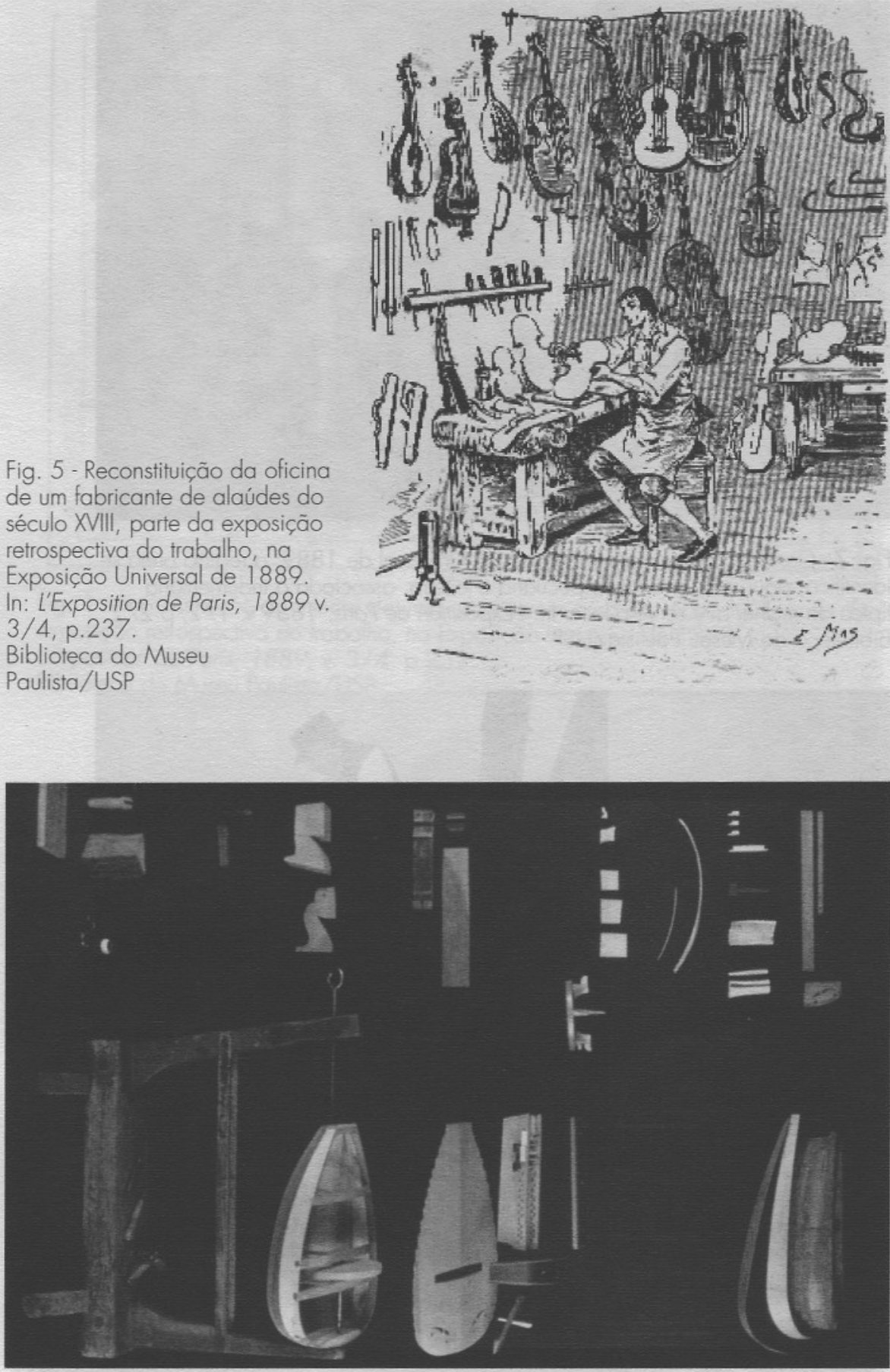

Fig. 6 - Conjunto sistemático de ferramentas e peças relativas à fabricação de instrumentos de corda usados na execução de músicas populares tradicionais, em exposição no Museu de Artes e Tradiçōes Populares, Paris. Copyright Réunion des musées nationaux 


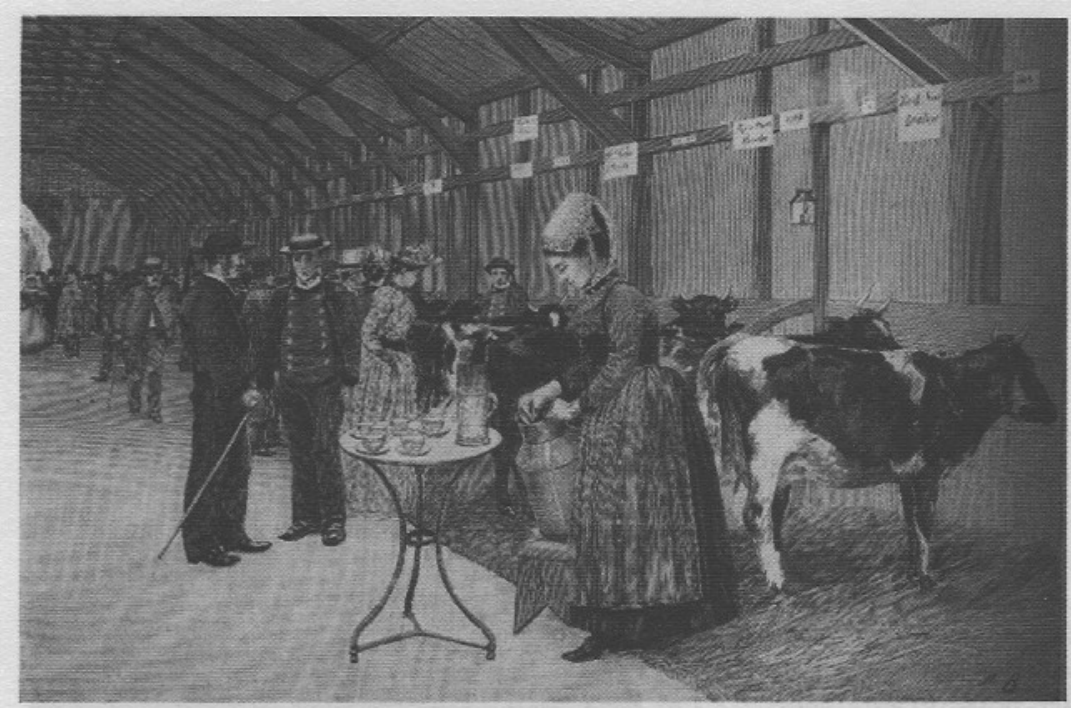

Fig. 7 - Concurso de animais na Exposição Universal de 1889: a região bretã se identifica, aqui, pela produção pecuária e leiteira, associada à indumentária típica da mulher que serve o leite. In: L'Exposition de Paris, 1889 v. 1/2, p. 272. Biblioteca do Museu Paulista/USP

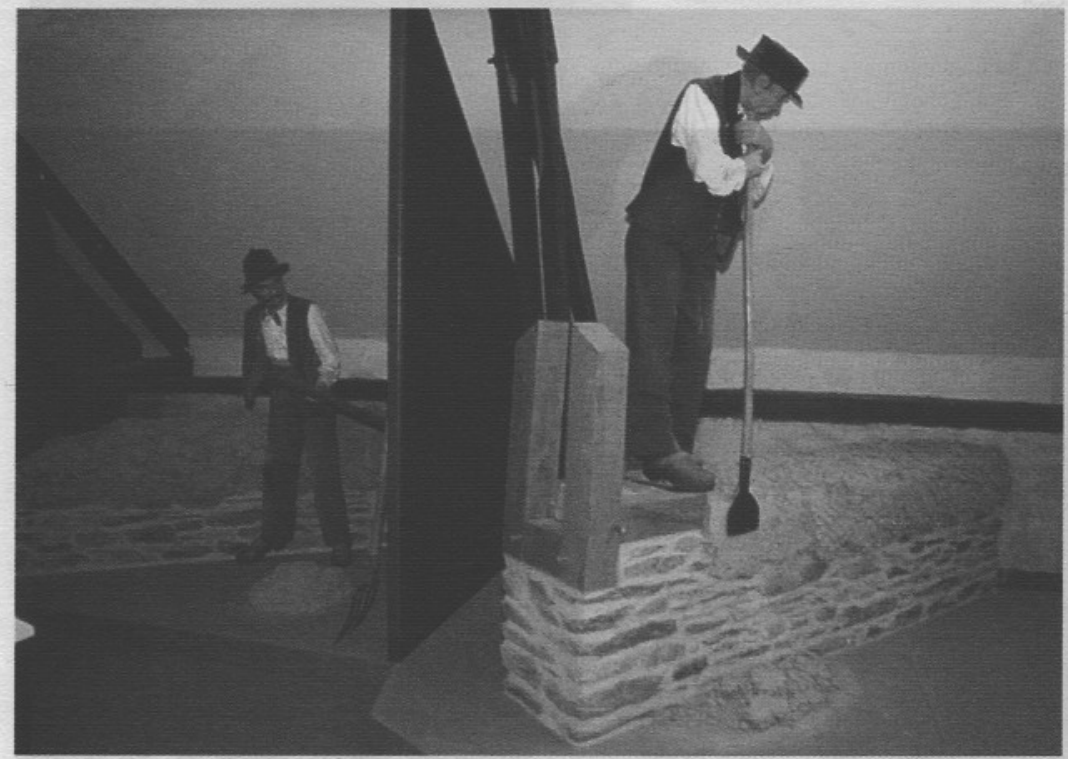

Fig. 8 - Detalhe da exposição central do Ecomuseu de Rennes, em que se mostram técnicas de construção em pedra, características da arquitetura tradicional da região. A presença dos "manequins-pedreiros", além de uma gravação que pode ser acionada para que se ouçam explicações sobre o que "está sendo feito", valorizam a atividade da construção e o conhecimento das respectivas técnicas tradicionais como patrimônio, tanto quanto as edificações em si.

Copyright Musée de Bretagne 


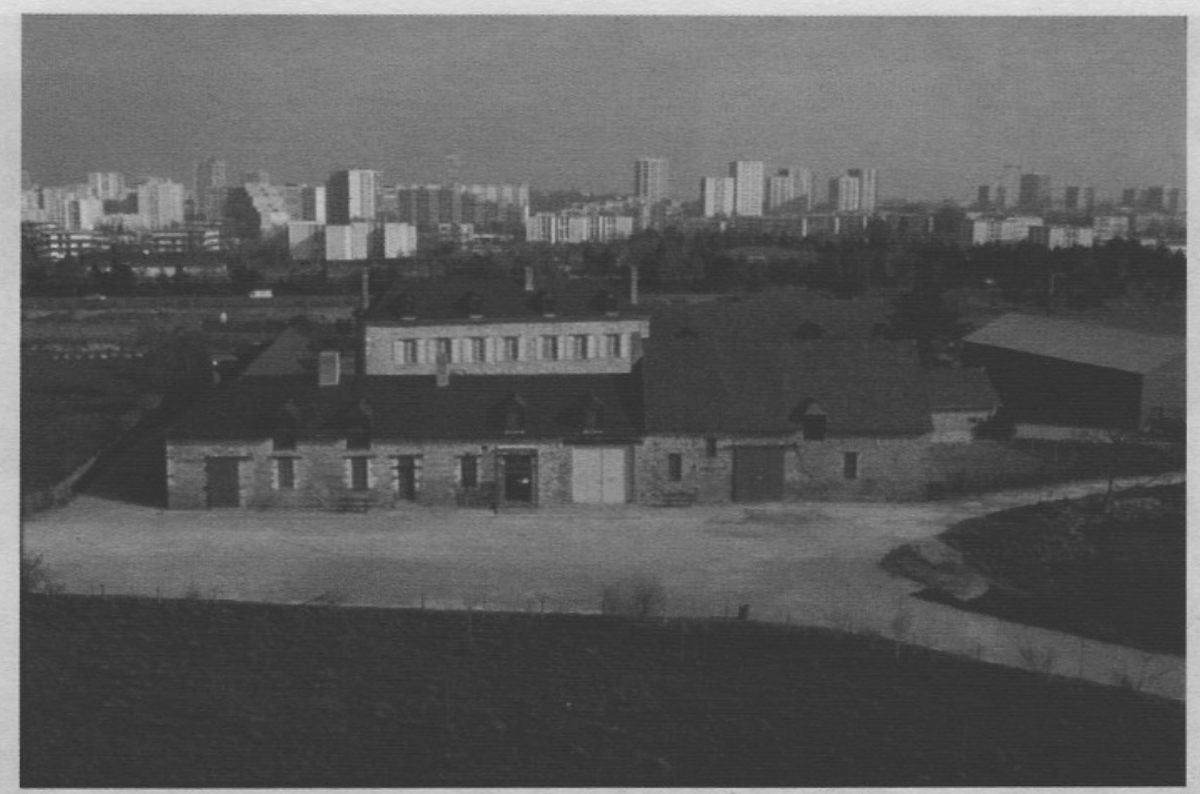

Fig 9 - Aspecto do Ecomuseu de Rennes, sediado numa antiga fazenda, que se encontra, hoje, em pleno espaço urbano.

Copyright Musée de Bretagne

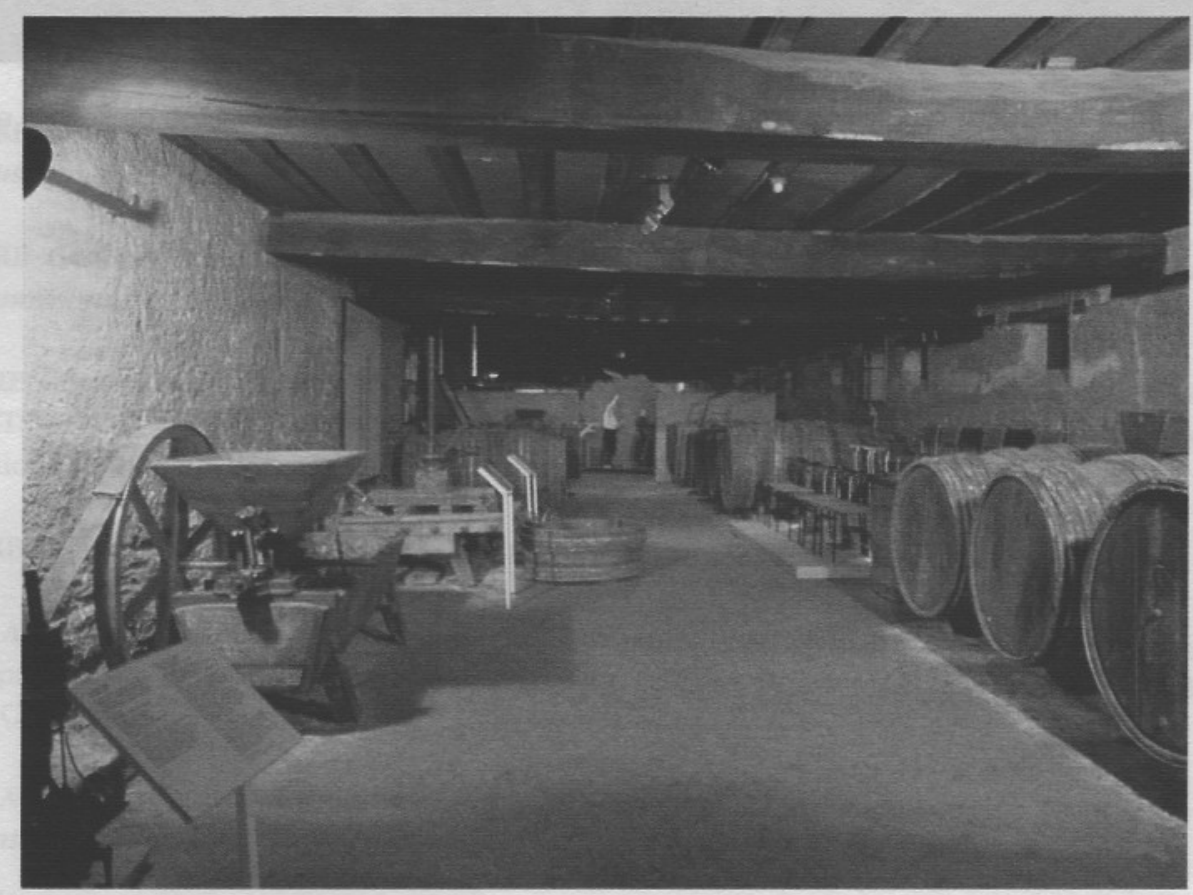

Fig. 10 - Série de barris e outros equipamentos de uso característico da região de Rennes, na exposição do Ecomuseu de Rennes.

Copyright Musée de Bretagne 


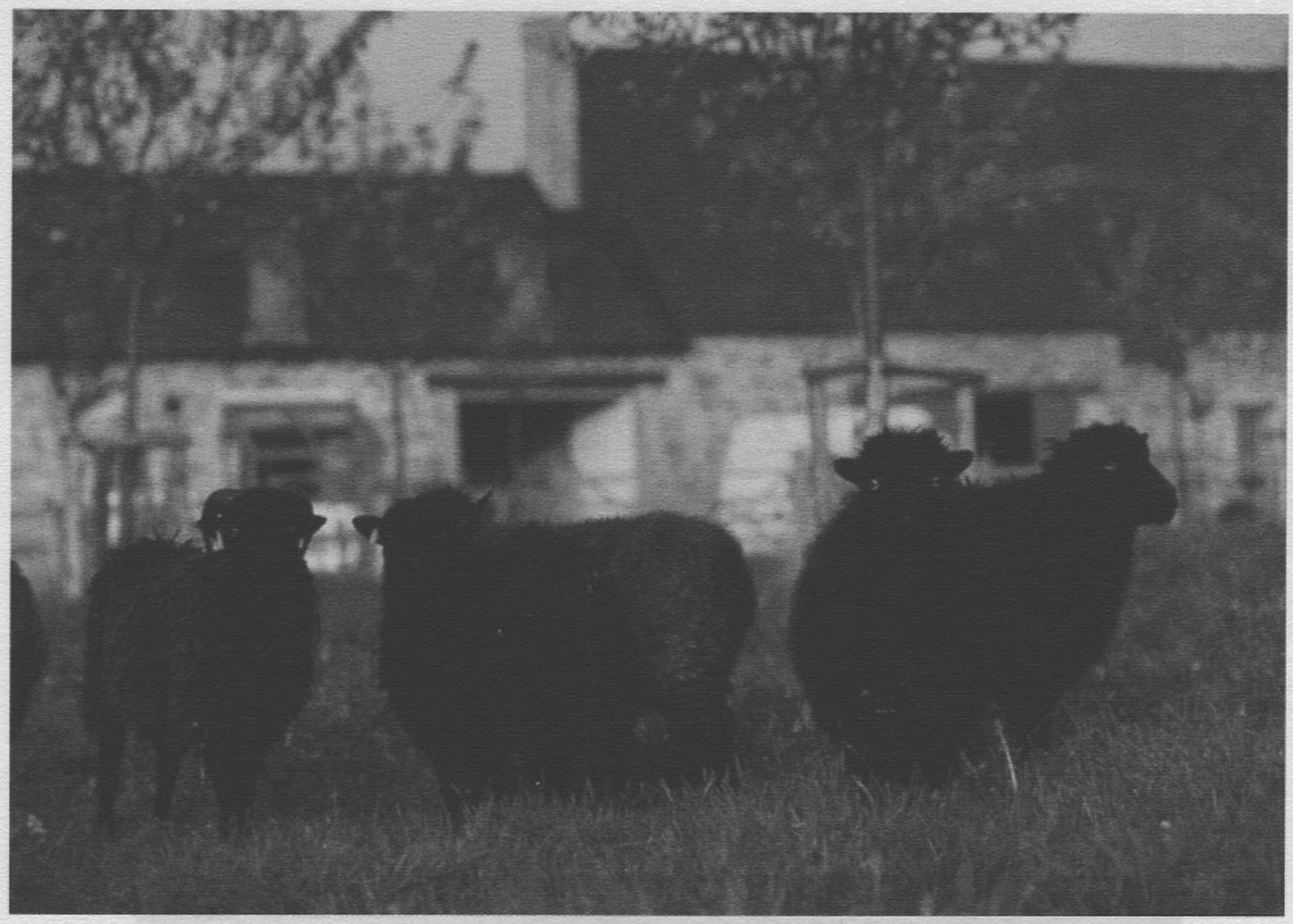

Fig. 11 - A criação de raças de animais em extinção é feita cientificamente no Ecomuseu de Rennes e no sentido de preservar o patrimônio genético do planeta. E utilizada, também, para fins educativos. Copyright Musée de Bretagne 
BIBLIOGRAFIA 
Pratos e mais pratos: louça doméstica, divisões culturais e limites sociais no Rio de Janeiro, século XIX

Tania Andrade Lima

A grande quantidade de louça doméstica que vem sendo recuperada em escavações arqueológicas, realizadas em unidades residenciais do séc.XIX, no Rio de Janeiro, levou a uma reflexão sobre o significado desses objetos para a sociedade que os incorporou tão intensamente ao seu cotidiano. O presente artigo analisa de que modo elas foram utilizadas para a manutenção dos limites, reforçando princípios sociais, e de que modo constituíram uma expressão da ordem então vigente no país.

Unitermos: Louça doméstica. Rio de Janeiro, séc.XIX. Arqueologia histórica

Anais do Museu Paulista, n.sér.,v.3, p.129-191, 1995.

Dishes and more dishes: domestic earthenware, cultural segments, and social limits in 19th-century Rio de Janeiro, Brasil

Tania Andrade Lima

The huge amount of domestic earthenware rescued by current archaeological excavations achieved in habitation sites in 19th-century Rio de Janeiro, asks for a reflection on the meaning of such a kind of artifact for a society that so intensively incorporated it into its everyday life. This article analyzes the ways use was made of earthenware in order to keep on social limits, thus strengthening social principles, and how it became an expression of the prevailing order.

Uniterms: Domestic earthenware. Rio de Janeiro, 19th-century. Historical Archaeology. Anais do Museu Paulista, n.sér, v.3, p.129-191, 1995.

O espetáculo do lpiranga: reflexões preliminares sobre o imaginário da Independência

Cecilia Helena de Salles Oliveira

Este artigo constitui uma incursão inicial em relação ao tema do imaginário da Independência. Toma como questão central a construção de um monumento no lpiranga, celebrativo da data de 7 de Setembro de 1822, e se propõe a discutir tal projeto, conforme foi formulado na década de 1870. Unitermos: Monumento do Ipiranga. Independência do Brasil. Imaginário.

Anais do Museu Paulista, n.sér. v.3, p.195-208, 1995.

The spectacle of Ipiranga: introductory remarks on the 'imaginaire' of Brasil's Independence

Cecilia Helena de Salles Oliveira

This article is a first approach on the 'imaginaire' of Brasil's Independence and deals with the project of a monument intended to celebrate the place where it was declared /the lpiranga fields in São Paulol and the date (September 8,1822 ). The discussion focus on the construction project put forward in the seventies of last century.

Uniterms: Ipiranga Monument. Brasil's Independence. History of the 'imaginaire'.

Anais do Museu Paulista, n.sér. v.3, p.195-208, 1995

A conformação dos ecomuseus: elementos para compreensão e análise

Heloisa Barbuy

Apresenta uma história dos ecomuseus enraizada nos movimentos de folclore e ennografia regional, do final do século XIX até os dias de hoje, examinando o caso francês. Explora aspectos em geral menos enfatizados neste campo, tal como a natureza e o papel atribuído aos acervos e ao patrimônio cultural e padrões museográficos.

Unitermos: Ecomuseu. História do ecomuseu. Museologia. Museografia. Museu de Folclore.

Anais do Museu Paulista, n.sér. v.3, p. 209-236, 1995. 
The shaping of ecomuseums: elements for analysis and understanding

Heloisa Barbury

This article seeks to trace an overall history of ecomuseums - especially in France - and to detect its roots in folkloristic as well as regional ethnography movements, from the end of the 19th-century until now. Aspects usually underrated are emphasized, as the role of collections and cultural heritage and the museographic patterns.

Uniterms: Ecomuseum. Histoy of the ecomuseum. Museology. Museography. Folklore Museum.

Anais do Museu Paulista, n.sér. v.3, p.209-236, 1995.

F. Braudel: tempo histórico e civilização material. Um ensaio bibliográfico

Antonio Penalves Rocha

A publicação recente da tradução brasileira da obra de Fernand Braudel, Civilisation matérielle et capitalisme, oferece uma boa oportunidade para o reexame de alguns aspectos deste livro. 0 presente ensaio pretende destacar a importância dada por Braudel às questões teóricas - principalmente sua concepção de tempo histórico e seu esforço para criar a unidade das ciências do homem - e o papel que desempenham na delimitação do objeto do livro.

Unitermos: Fernand Braudel. Tempo histórico. Civilização material

Anais do Museu Paulista, n.sér.v.3, p.239-249, 1995.

F.Braudel: historical time and material civilization. A bibliographical essay.

Penalves Rocha

The recent appearance of a Brasilian translation of Fernand Braudel's Civilisation matérielle et capitalisme is a good opportunity to reexamine some aspects of this seminal book and to seek to bound its central object. Special attention is called to the importance assigned by Braudel to some theoretical issues, under the aegis of "material civilization", mainly his concept of historical time and his effort to unify the social sciences.

Uniterms: Fernand Braudel. Historical time. Material civilization.

Anais do Museu Paulista, n.sér. v.3, p.239-249, 1995

Indumentária e moda: uma seleção bibliográfica em Português

Adilson José de Almeida

Foram descritivamente listados livros e capítulos de livros, traduzidos ou originalmente escritos em português, entre 1979 e 1996 e referentes a vários aspectos da indumentária e da moda. O objetivo é fornecer um quadro de referência de acesso imediato tanto para o especialista, como para o leigo. A lista propriamente dita está precedida por uma caracterização geral da bibliografia e por um tratamento mais demorado daqueles autores que se considerou representarem algumas importantes vertentes neste domínio.

Unitermos: Indumentária. Moda. Bibliografia seletiva e descritiva.

Anais do Muscu Paulista, n.sér. v.3, p.251-296, 1995.

Clothes and fashion: a select bibliography in Portuguese

Adilson José de Almeida

Books and book chapters, originally witten in Portuguese or translated into it, fom 1979 to 1996 , and related to several aspects of clothes, clothing and fashion are listed in order to provide an easily available frame of references for specialists as well as for laymen. The listing is preceded by a brief characterization of the bibliography and by a more detailed treatment of those authors considered to represent some impotant streams in this field.

Uniterms: Clothes. Fashion. Select descriptive bibliography Anais do Museu Paulista, n.sér. v.3, p.251-296, 1995 